
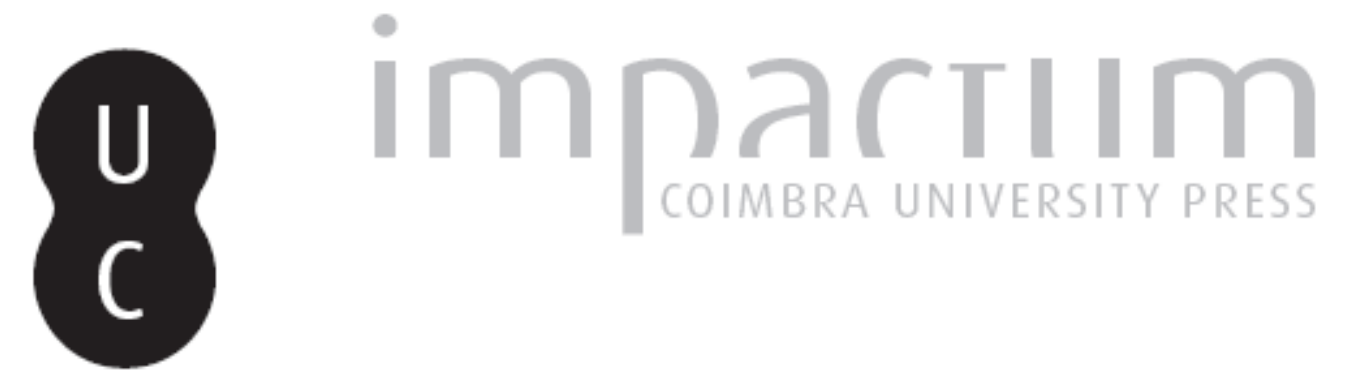

\title{
Notas para a história da Biblioteca Pública de Ponta Delgada
}

\section{Autor(es): Silva, Susana Serpa}

Publicado por: Centro de História da Sociedade e da Cultura

URL persistente:

URI:http://hdl.handle.net/10316.2/39434

DOI:

DOI:http://dx.doi.org/10.14195/1645-2259_12_13

Accessed : $\quad$ 26-Apr-2023 12:18:46

A navegação consulta e descarregamento dos títulos inseridos nas Bibliotecas Digitais UC Digitalis, UC Pombalina e UC Impactum, pressupõem a aceitação plena e sem reservas dos Termos e Condições de Uso destas Bibliotecas Digitais, disponíveis em https://digitalis.uc.pt/pt-pt/termos.

Conforme exposto nos referidos Termos e Condições de Uso, o descarregamento de títulos de acesso restrito requer uma licença válida de autorização devendo o utilizador aceder ao(s) documento(s) a partir de um endereço de IP da instituição detentora da supramencionada licença.

Ao utilizador é apenas permitido o descarregamento para uso pessoal, pelo que o emprego do(s) título(s) descarregado(s) para outro fim, designadamente comercial, carece de autorização do respetivo autor ou editor da obra.

Na medida em que todas as obras da UC Digitalis se encontram protegidas pelo Código do Direito de Autor e Direitos Conexos e demais legislação aplicável, toda a cópia, parcial ou total, deste documento, nos casos em que é legalmente admitida, deverá conter ou fazer-se acompanhar por este aviso.

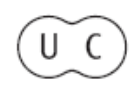


evista de História da Sociedade e da Cultura

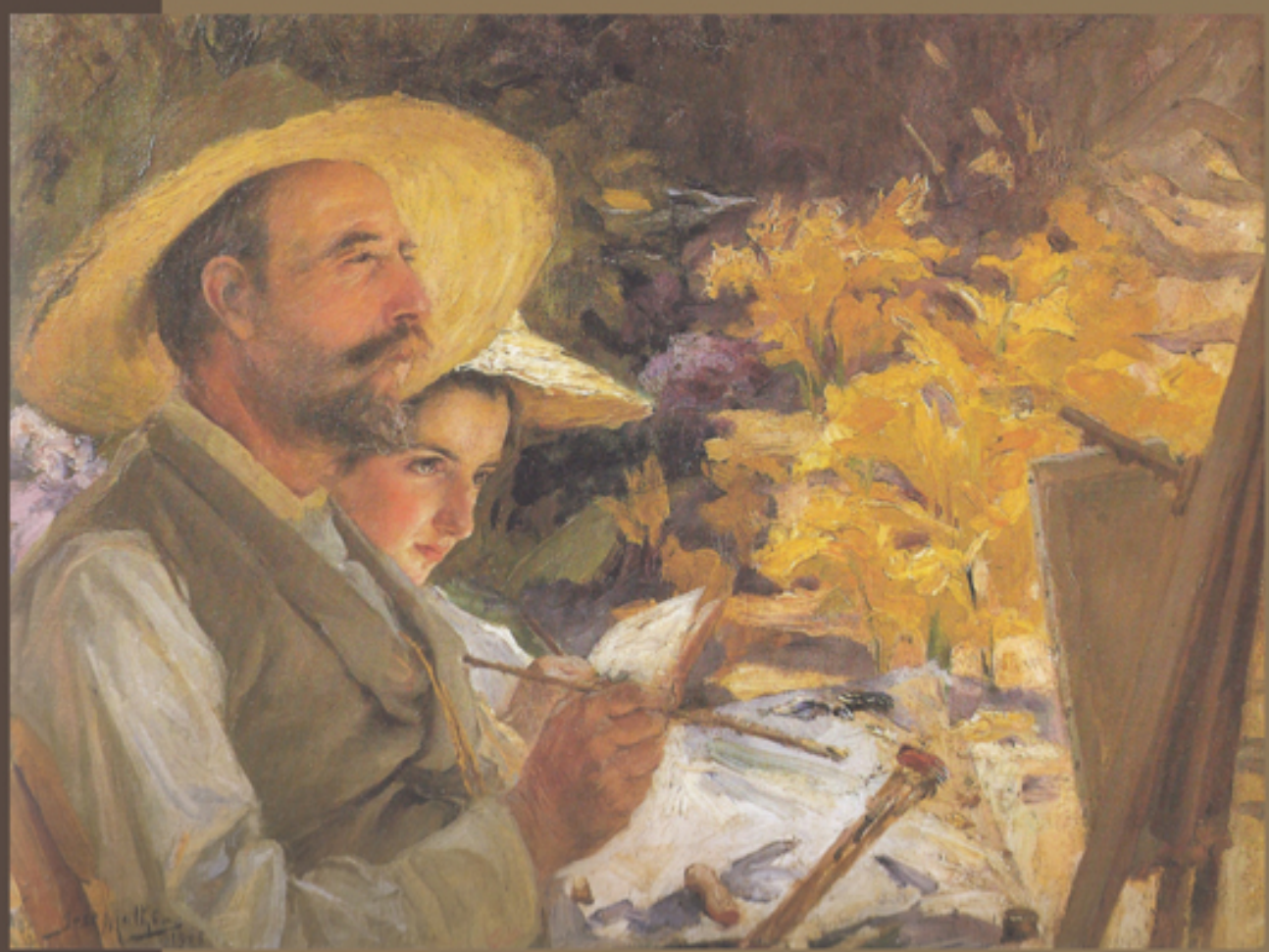

Centro de História da Sociedade e da Cultura Universidade de Coimbra 


\title{
Notas para a história da Biblioteca Pública de Ponta Delgada*
}

\author{
Susana Serpa Silva** \\ Universidade dos Açores \\ Centro de História de Além-Mar (CHAM) \\ sserpasilva@sapo.pt \\ Texto recebido em /Text submitted on: 17/05/2012 \\ Texto aprovado em /Text approved on: 20/12/2012
}

\section{Resumo/Abstract:}

Entre os diferentes equipamentos culturais de uma localidade, as Bibliotecas Públicas desempenharam, desde o século XVIII, um relevante papel de cariz educativo e civilizacional. Abertas para servir um público vasto e diversificado, estas instituições, que se multiplicaram em Portugal ao longo do século XIX, tornaram-se importantes símbolos do progresso sociocultural e urbano mesmo quando enfrentavam dificuldades orçamentais ou logísticas. Foi o caso da Biblioteca Pública de Ponta Delgada que tendo sido fundada em 1841, só foi inaugurada cinco anos depois. Os seus responsáveis lutaram com inúmeras vicissitudes que, todavia, lograram paulatinamente ultrapassar, permitindo a manutenção do seu funcionamento até aos nossos dias. Uma vez que esta instituição não tem merecido a devida atenção por parte de académicos e estudiosos, pretende-se, com este artigo, dar um pequeno contributo para a história da Biblioteca Pública de Ponta Delgada, considerando o seu funcionamento enquanto instituição e o seu desempenho a nível cultural e social.

Between the different cultural facilities of a village, public libraries have played, since the 18th century, a relevant role of educational and civilizing nature. Open to serve a broad and diverse audience, these institutions, which have multiplied in Portugal throughout the 19th century, became important symbols of cultural and urban progress even when faced budgetary or logistics difficulties. This was the case of the Public Library of Ponta Delgada that having been founded in 1841 , it was only inaugurated five years later. Responsible fought with numerous problems, however, managed to gradually overcome, allowing the maintenance of this institution until the present day. Since its history does not have deserved due attention from academics and scholars, with this article it is intended to give some notes about the Public Library of Ponta Delgada, considering its functioning as an institution and its cultural and social level performance.

Palavras chave/Keywords:

Biblioteca Pública; Equipamentos culturais; Livros; Leitura.

Public libraries; Cultural facilities; Books; Reading. 


\section{Introdução}

Quando o livro deixou de ser um objecto raro, manuscrito e individual, a existência de bibliotecas tornou-se extremamente relevante, pois além de contribuirem para a conservação, organização e divulgação de livros, opúsculos e documentos, desde logo serviram como repositório e testemunho da memória colectiva, das experiências existenciais, culturais e científicas de uma dada época.

Se as primeiras bibliotecas tinham carácter particular, respondendo às necessidades, aos gostos e às tendencias coleccionistas de figuras inerentes a restritos círculos sociais, a partir do séc. XV terão surgido os antepassados das bibliotecas públicas, em resultado da abertura de acervos particulares ao uso colectivo, por iniciativa dos respectivos proprietários e em cidades com Munique ou Genebra. Depois, por meados do séc. XVIII, a criação das chamadas "salas ou gabinetes de leitura", graças a alguns livreiros que procuravam popularizar as suas livrarias, ajudou a cimentar o hábito das consultas públicas. Em troca de uma pequena mensalidade, qualquer indivíduo podia viajar pelo universo do imaginário, dos sonhos, do prazer, da ciência ou da cultura ${ }^{1}$.

A Revolução Francesa, a Revolução Industrial, o incremento da imprensa periódica e do urbanismo contribuiram, decisivamente, desde finais de setecentos e ao longo do séc. XIX, para a afirmação e difusão das bibliotecas públicas. Em Inglaterra, por exemplo, o Public Libraries Act de 1850 foi a primeira lei a regular a abertura e o funcionamento destas instituições, embora, na realidade, como referem alguns autores, tenha sido apenas a forma de legalizar ou regulamentar as bibliotecas e as práticas já há muito existentes, ainda que, daí por diante, tenha aumento consideravelmente o número de bibliotecas públicas em todo o país².

1 ARRUDA, Guilhermina Melo - As Práticas da Biblioteca Pública a partir das suas quarto funções básicas, http://dici.ibict.br/archive/00000734/01/T079.pdf. Veja-se também: BLACK, A. - A New History of the English Public Library: social and intellectual contexts, 1850-1914, London: Leicester University Press, 1996.

2 DAVIES, Steve - "History of public Libraries", in Taking Stock: the future of our public library service, Unison, September 2008, www.unison.org.uk/acrobat/17301.pdf. 
A urgência, prática e civilizacional, de instruir e até de qualificar a classe laboral contribuiu para o desenvolvimento destas instituições onde se podia praticar a leitura e até investir na prepração intelectual, critério cada vez mais relevante entre os mecanismos propiciadores de ascensão social. Talvez por isso, ainda nos finais do séc. XIX, o grande papel atribuído às bibliotecas era o da educação. Daí o poder afirmar-se que a razão de ser "da biblioteca de carácter público correspondeu, eminentemente, à função educacional"’3 $\mathrm{e}$ também moral, a ponto de em algumas sociedades oitocentistas, serem vistas como uma alternativa à bebida e ao crime, uma vez que eram acessíveis a todos e facultavam importantes hábitos de leitura ${ }^{4}$.

Como refere Bob Usherwood, entre os papéis tradicionais das bibliotecas públicas pode incluir-se "a preservação de material, auxiliando a investigação e a educação, o fornecimento de informação e o fornecimento de instalações culturais e recreativas"s. O relevo dado a cada papel foi variando consoante o local e a época, mas uma coisa é certa: ao conservarem e preservarem os livros e a documentação as bibliotecas tornaram-se "espírito e memória colectiva" de uma dada sociedade ${ }^{6}$.

No Portugal liberal de oitocentos foram também as preocupações com a instrução dos menos favorecidos que motivaram a abertura de bibliotecas públicas. Se era desejo dos governantes "formar estadistas esclarecidos, funcionários diligentes e cidadãos capazes de prover as carências da administração pública, havia que por ao seu alcance os instrumentos do saber"7. Assim, à semelhança da França, onde já existiam muitas bibliotecas públicas, D. Pedro IV mandou criar a 9 de Julho de 1833, por intermédio do ministro Cândido José Xavier, a Real Biblioteca Pública do Porto, como depósito de "todos os conhecimento humanos", onde os cidadãos pudessem livremente consultar fontes da ciências e saciar a sede de instrução ${ }^{8}$. A Real Biblioteca Pública da Corte, em Lisboa, mantinha-se em

3 Idem.

4 USHERWOOD, Bob - A Biblioteca Pública como Conhecimento Público, Lisboa: Caminho, 1999, p. 22.

5 Idem, p. 21.

6 Idem, ibidem.

7 SERRÃO, Joaquim Veríssimo - História de Portugal, 1832-1851, Lisboa: Verbo, 1986, vol.VIII, p. 370.

${ }^{8}$ Apud SERRÃO, Joaquim Veríssimo - idem, p. 370. 
funcionamento desde o reinado de D. Maria I, altura em que tinha sido criada por alvará de 29 de Fevereiro de 1796. Mais tarde, instalada no Convento de S. Francisco, viria a transformar-se na Biblioteca Nacional de Lisboa. O regime liberal tentou melhorar algumas das suas deficiências, alargando o horário de leitura, bem como o corpo de bibliotecários e de funcionários, reafirmando a ampliando também o depósito legal ${ }^{9}$.

Em ambos os casos referidos, foram incorporadas as colecções das livrarias dos antigos e numerosos conventos e mosteiros, logo após a extinção das ordens religiosas masculinas, o que permitiu evitar a destruição ou o desaparecimento de algumas espécies raras e valiosas, não obstante muitas terem sido roubadas e perdidas. Para além das bibliotecas integradas em estabelecimentos de ensino - como as Universidades (de onde se destaca a Biblioteca Joanina, concluída em 1728) ou as Escolas Médico-Cirúrgicas -, emergiram as bibliotecas oficiais, como a das Cortes, então criada pelo governo setembrista e as Bibliotecas Públicas que se difundiram pelo reino e ilhas adjacentes, em diferentes capitais de distrito: Vila Real, Braga, Funchal, Évora e Ponta Delgada, na ilha de S. Miguel, as quais, de acordo com Oliveira Marques, "marcaram o começo de uma nova era"10.

\section{A fundação da Biblioteca Pública de Ponta Delgada}

Não obstante se dever ao Setembrismo um relevante movimento de criação de bibliotecas laicas, muitas delas de perfil distrital e local substitutas das velhas livrarias eclesiásticas -, apenas a 10 de Dezembro de 1841 decretou a Rainha D. Maria II a criação de uma biblioteca pública na cidade de Ponta Delgada. A medida foi considerada então, pelos locais, como um acto de justiça para com um aglomerado da importância e dimensão que este assumia. De facto, apesar da sua condição de urbe insular,

9 Cf. MARQUES, A. H. de Oliveira, coord. - Portugal e a Instauração do Liberalismo, vol. IX, Nova História de Portugal, dir. de Joel Serrão e A. H. de Oliveira Marques, Lisboa: Editorial Presença, 2002, p. 425. Veja-se também: TORGAL, Luís Reis e VARGUES, Isabel Nobre - "Espaços de Leitura", in MATTOSO, José, dir. - História de Portugal. O Liberalismo, coord. de TORGAL, Luís Reis e ROQUE, João, Lisboa: Editorial Estampa, 1993, vol. 5, pp. 687 e ss.

${ }^{10}$ Idem, p. 429. 
Ponta Delgada conheceu, neste período, algumas iniciativas de vulto no campo cultural, em parte graças a uma geração empreendedora e dinâmica do ponto de vista social e intelectual.

Em 1835 surgiu o jornal O Açoriano Oriental importante folha generalista/ /regionalista que logrou sobreviver até ao século XXI, graças ao contributo e ao empenhamento de jornalistas e de homens de letras micaelenses. As relevantes reformas de Passos Manuel terão motivado a criação de uma Sociedade de Alunos de Direito de Ponta Delgada e a instituição de uma Escola Médico-Cirúrgica, que começou a funcionar no ano lectivo de 1839-40. Influentes proprietários locais fundaram a Sociedade Promotora da Agricultura Micaelense que protagonizou um considerável desempenho no domínio da agronomia, dispondo de órgão próprio e que era o periódico O Agricultor Micaelense. Além de assinaláveis melhoramentos urbanos (como a iluminação com candeeiros de azeite), não muito tempo depois, em Setembro de 1848, seria fundada a Sociedade dos Amigos das Letras e Artes, presidida por António Feliciano de Castilho e que viria a desempenhar notáveis funções a nível pedagógico, literário e filantrópico. É, pois, neste contexto que emergiu a Biblioteca Pública igualmente em prol do progresso da cidade e da ilha ${ }^{11}$, ainda que a campanha empreendida em prol da sua fundação remonte a inícios da década de $30^{12}$.

Segundo Urbano de Mendonça Dias, o projecto desta instituição foi concebido e apresentado às Cortes pelos três deputados eleitos pelo respectivo Distrito, António Vicente Peixoto (Barão de Santa Cruz), Francisco Afonso da Costa Chaves e Melo e João Joaquim da Costa Simas ${ }^{13}$.

${ }^{11}$ Cf. FARIA E MAIA, Francisco d'Ataíde Machado de - Novas Páginas da História Micaelense (subsídios para a História de S. Miguel - 1832-1895), 2a edição, Ponta Delgada: Jornal de Cultura, 1994, pp. 194 e ss (ed. original: 1947). Veja-se também SILVA, Susana Serpa - "Aspectos da vida cultural e social micaelense na segunda metade do século XIX", separata de Arquipélago-História, 2ª série, vol. IV, nº 2, 2000, pp. 299-358.

${ }^{12}$ Segundo Aníbal Bicudo os primeiros esforços no sentido de dotar a cidade de uma instituição desta natureza remontam a 1833 e em 1835 foi mesmo criada uma comissão, por alvará de 18 de Agosto da antiga Prefeitura, com a finalidade de colher donativos para a projectada livraria. BICUDO, Aníbal - Em Louvor do IV Centenário da Cidade de Ponta Delgada. "Poeiras do Passado”, Ponta Delgada: Edição da Câmara Municipal de Ponta Delgada / Of. do "Diário dos Açores", 1946, p. 61.

${ }^{13}$ DIAS, Urbano de Mendonça - Ponta Delgada. Monografia histórica, Vila Franca do Campo: Tipografia A Crença, 1946, p. 103. 
Estes dados são confirmado por Aníbal Bicudo que transcreve o projecto de lei que os mesmos apresentaram na sessão de 16 de Janeiro de 1841e que viria a ser convertido em lei ${ }^{14}$ :

"Senhor! A instrução tem sido constantemente a primeira necessidade do homem no meio da sociedade como fonte perene dos bons costumes, e verdadeiro apoio das liberdades públicas: é por isso que ela merece a maior atenção do Legislador na grande obra da civilização. Os povos com tão poderoso elemento saboreiam os frutos da associação, os estados prosperam e os governos têm força.

Possuídos destas idéias, os deputados pela Província Oriental dos Açores, vêem propor-vos a criação de uma Biblioteca na Cidade de Ponta Delgada com o intuito de promover entre os seus constituintes o derramamento das Luzes, e a aquisição de conhecimentos proveitosos, sem todavia pretenderem sobrecarregar o Tesouro da Nação".

Entre alguns dos pressupostos definidos quanto ao estabelecimento desta instituição avultava a autorização para ser despendida a quantia de 1 conto de réis em obras no extinto Convento dos Gracianos (que albergava as aulas do ensino primário e secundário), bem como a doação de todos os livros pertencentes aos extintos conventos das ilhas de S. Miguel e de Santa Maria. Ainda em conformidade com Mendonça Dias, até à fundação da Biblioteca numa sala do referido convento, haviam-se amontoado cerca de 5.000 livros, oriundos das bibliotecas conventuais, num antigo granel do Convento da Esperança ${ }^{15}$, com grande perigo de se irem degradando.

Versão um pouco diferente é avançada por Francisco Machado de Faria e Maia. Segundo este estudioso terá sido o Governador Civil a solicitar ao governo um subsídio para que a Biblioteca se instalasse numa dependência do Convento da Esperança, prevendo-se gastar um montante de 400 mil réis com as despesas das obras. Todavia, concedido o subsídio, veio a verificar-se que o local não era apropriado e daí a solução encontrada nas instalações do Convento da Graça, cujas obras, porém, seriam mais dispendiosas ${ }^{16}$. De facto, em conformidade com Aníbal Bicudo, por carta enviada pelo Barão de Santa Cruz ao Ministro do Reino (na altura Rodrigo da Fonseca Magalhães),

\footnotetext{
${ }^{14}$ BICUDO, Aníbal - Em Louvor ... cit., p. 56-57.

15 DIAS, Urbano de Mendonça - Ponta Delgada ... cit., p. 104.

${ }^{16}$ FARIA E MAIA, Francisco d'Ataíde Machado de - Novas Páginas ...cit., p. 210.
} 
na sequência da proposta do "Administrador Geral do Distrito de Ponta Delgada sobre o estabelecimento de uma Biblioteca no granel do Convento da Esperança, datada de 28 de Abril de 1841", é reforçada a necessidade de estabelecer a Biblioteca no Convento da Graça, tanto por economia, como por comodidade, uma vez que o referido granel se achava em estado de ruína e ficava distante das escolas do ensino primário e secundário que, na altura, funcionavam no edifício dos Gracianos ${ }^{17}$.

Por estas considerações pode depreender-se as preocupações e os esforços despendidos pelos dirigentes de então, sem que tenha sido despicienda a colaboração de alguns cidadãos que acabou, aliás, por ser tornar assaz significativa. Já no século XIX, Francisco Maria Supico refere que entre o grupo dos que coadjuvaram o Governador Civil, se contava o comendador José Caetano Dias do Canto e Medeiros que, por exemplo, se voluntariou a inspecionar as obras da sala destinada à Biblioteca ${ }^{18}$. O Administrador do Concelho, por seu turno, promoveu uma subscrição pública por meio da qual terá arrecadado mais de $20 \$ 000$ réis doados por 167 subscritores. Ademais, a doação de livros e de colecções, por parte de particulares, coube a Jacinto Inácio da Silveira, $1^{\circ}$ Barão de Fonte Bela que doou 600 volumes, a José Jácome Correia que ofereceu 40 e a Bernardino José de Sena Freitas que ofertou os 8 volumes das obras de Homero ${ }^{19}$. Tudo leva a crer que as afirmações de Supico terão servido de base às descrições de Francisco Faria e Maia.

Não obstante o inicial dinamismo, a organização da nova instituição viria a ser bastante demorada. A abertura ao público seria mesmo protelada por falta de condições. Era necessário, em primeiro lugar, proceder à catalogação e arrumação dos livros e, para isso, era fundamental um bibliotecário que, a tempo inteiro, assegurasse estas funções e possibilitasse o cabal funcionamento da sala de leitura, coadjuvado por um contínuo.

${ }^{17}$ BICUDO, Aníbal - Em Louvor ... cit., p. 59-60.

${ }^{18}$ A sala terá sido construída na ala onde existiam um corredor e celas do antigo Mosteiro de Santo Agostinho e na qual estava instalada a Administração do Concelho que teve de passar para outras dependências do mesmo mosteiro até ser transferida para o profanado convento da Conceição. BICUDO, Aníbal - Em Louvor ... cit., p. 61.

${ }^{19}$ SUPICO, Francisco Maria - "Escavações", A Persuasão, no 1825, 6 de Janeiro de 1897 ou in As Escavações de Francisco Maria Supico, Ponta Delgada: Instituto Cultural de Ponta Delgada, 1995, vol. I, p. 186-187. 
O primeiro bibliotecário foi Thomas Brown Soares. Era oficial da Biblioteca Nacional de Lisboa e foi promovido a bibliotecário da de Ponta Delgada, por decreto de 28 de Junho de 1842. Enquanto o Governo Civil ordenava que se mandasse proceder à encomenda de bancos para acomodação dos leitores que ali concorressem "a instruir-se"20, a rainha recomendava ao mesmo Governo Civil que fossem efectuadas todas as diligências para promover os trabalhos de "catalogação e classificação dos livros, em cada uma das grandes secções dos conhecimentos humanos", além do envio dos respectivos relatórios e estatísticas referentes às aquisições de livros e leituras anuais, conforme o modelo da congénere de Lisboa ${ }^{21}$.

Quando Thomas Brown chegou a Ponta Delgada recebeu os livros dos extintos mosteiros de S. Francisco e da Graça, alguns que se encontravam no Hospício da Caloura e perto de 700 volumes dados por alguns habitantes da cidade. Eram mais de 5 mil volumes, todos na maior confusão, alguns sem capas e até estragados. O encarregado abraçou a morosa tarefa da catalogação - com catálogos alfabéticos e metódicos - e depois de pronto o edifício, colocou os livros nas respectivas estantes. Assim, apenas em 1845 o estabelecimento estava pronto para o funcionamento público, sendo, porém, esta a apreciação do seu responsável:

"Os cinco mil volumes de que se compõe esta Biblioteca são pela maior parte pertencentes a Ciências Eclesiásticas; entre eles se acham alguns de merecimento; porém nenhum de grande valor. Em História Eclesiástica se encontra alguma coisa; mas nada em História Civil. Em Belas Letras, pouquíssimas obras. Em Ciências Naturais e Filosóficas, Artes e Ofícios, alguns volumes: os mais de Filosofia. De Matemáticas, Medicina, Agricultura, quase nada. História Natural, nada. Em Jurisprudência, muito pouco. Em Direito Civil apenas as Ordenações impressas em S. Vicente em 1695 por mandado do Sr. Rei D. Pedro $2^{\circ}$, e outra edição mandada imprimir no mesmo Mosteiro por El-Rei D. João $5^{\circ}$, em 1747-54, e nada mais em Legislação Pátria. Em Direito Canónico, muito pouco. Manuscritos, nada.

${ }^{20}$ BPARPD (Biblioteca Pública e Arquivo Regional de Ponta Delgada) - FBPARPD (Fundo da Biblioteca Pública e Arquivo Regional de Ponta Delgada) - Série 004, Lv 19, Correspondência Recebida, Ofício do Governo Civil, 1843.

${ }^{21}$ BPARPD - FBPARPD - Série 004, Lv 19, Idem, Ofício do Governo Civil, 7 de Janeiro de 1846. 
Eis o estado desta Biblioteca que bem pouco satisfaz às necessidades dos Estudiosos que a frequentam"22.

Apesar do moroso processo de instalação, esta era uma Biblioteca muito incompleta, pouco abrangente e actualizada, uma vez que, pela proveniência do espólio, permanecera demasiado circunscrita à literatura eclesiástica e religiosa. Esta situação porém, não seria apanágio deste estabelecimento. A Real Biblioteca de Lisboa, há não muito tempo atrás, enfermava de idênticas deficiências tal como outras bibliotecas portuguesas. Como referiu Adrien Balbi, em 1822, havia falta de "quase todos os livros modernos, científicos e literários, ultimamente publicados pelos Ingleses, Franceses, Alemães e Italianos". Quase não existiam os de "geografia e estatística modernas; não possuía mesmo qualquer dos numerosos atlas publicados desde finais do século passado até hoje"23. Por isso, os governos liberais tiveram de se empenhar no seu melhoramento. Assim o comprova Paulo Barata ao relevar a importância das bibliotecas no âmbito das políticas culturais de oitocentos que privilegiaram, precisamente, as bibliotecas públicas em detrimento das conventuais, então extintas, suscitando uma mudança de paradigma: do religioso para o laico, do domínio restrito ou privado para o público alargado ${ }^{24}$.

No tocante a Ponta Delgada, e segundo Aníbal Bicudo, já em Abril de 1843, os deputados Bento Cardoso de Gouveia Pereira Corte Real e Barão de Santa Cruz haviam solicitado ao Ministério do Reino o enriquecimento do espólio da livraria pública com livros do Depósito Geral que eles próprios se comprometiam a escolher ${ }^{25}$. Dois anos mais tarde, o próprio Thomas Brown Soares voltava a sugerir idêntica solução. Em sua opinião, e sem grande prejuízo para o Tesouro Público, urgia fazer transportar para a ilha alguns milhares de obras, de todos os ramos, oriundas do Depósito das Livrarias, a cargo da Biblioteca Nacional de Lisboa, que ainda dispunha, àquela altura, de 200 mil volumes. Só assim, de forma célere, se poderia

${ }^{22}$ BPARPD - FBPARPD - Série 004, Lv 20, Correspondência Expedida, Ofício dirigido ao Ministério do Reino, 22 de Setembro de 1845, fl. 2.

${ }^{23}$ Apud MARQUES, A. H. de Oliveira, coord. - Portugal e a Instauração ... cit., p. 425.

${ }^{24}$ Veja-se BARATA, Paulo J. S. - Os Livros e o Liberalismo: da livraria conventual à biblioteca pública. Uma alteração de paradigma, Lisboa: Biblioteca Nacional, 2003.

${ }^{25}$ BICUDO, Aníbal - Em Louvor ... cit., p. 63-64. 
suprimir as graves lacunas da nova Biblioteca, para além, claro, de outras carências imediatas como eram uma escada, tinteiros e um imprescindível Manual de Livreiros para auxílio à catalogação ${ }^{26}$. Contudo, no final de 1846, a justa pretensão do bibliotecário ainda não tinha sido concretizada. No ano anterior, como reflexo da era cabralista, as novas aquisições da instituição, através do Governo Civil, foram uma obra e um folheto que resumiam a vida pública de dois protagonistas do parlamentarismo e da governação portuguesa: Apontamentos Históricos para a vida do Il. E Exmo. António Bernardo Costa Cabral e Duas Palavras sobre os Serviços e Mérito do Ilmo. E Exmo. Sr. José Bernardo da Silva Cabral. A sua leitura, dizia-se, devia servir de testemunho "à mocidade estudiosa"27, confirmando, uma vez mais, a percepção das Bibliotecas Públicas como instituições de instrução.

Não obstante os constrangimentos e as limitações, urgia inaugurar oficialmente o novo equipamento cultural e urbano de Ponta Delgada. Por isso, a abertura solene da Biblioteca Pública foi agendada para o dia 11 de Janeiro de 1846. Pela 1 hora da tarde e no salão principal, reuniram-se as autoridades e os ilustres da terra. Coube ao Comissário dos Estudos do Distrito, o Reverendo João José de Amaral proferir o eloquente discurso inaugural, depois do Governador Civil ter dado a posse do estabelecimento ao presidente da Câmara Municipal ${ }^{28}$.

Por decreto de 12 de Março de 1845 fora cedido à edilidade o encargo com a conservação e o funcionamento da Biblioteca Pública ${ }^{29}$. O município passava a ter de assegurar os vencimentos dos funcionários sem habilitações (contínuos), as despesas com a compra de livros (foi estabelecida uma dotação anual de $50 \$ 000$ réis), de materiais de limpeza ou outros, como tinteiros, papel ou copiadores de correspondência e ainda tinha de garantir as obras que fossem necessárias. Estas determinações vieram representar

${ }^{26}$ BPARPD - FBPARPD - Série 004, Lv 20, Idem, Ofício dirigido ao Ministério do Reino, 22 de Setembro de 1845, fls. 2 e 2v.

${ }^{27}$ BPARPD - FBPARPD - Série 004, Lv 19, ob. cit., Ofício do Governo Civil, 23 de Setembro de 1845.

${ }^{28}$ BPARPD - FBPARPD - Série 004, Lv 20, Idem, Ofício dirigido ao Ministério do Reino (Conde de Tomar), fl. 3.

${ }^{29}$ Tal como sucedera com a Biblioteca Pública do Porto, o estabelecimento foi considerado pertença da cidade e, por isso, a gestão recaiu sobre a respectiva Câmara. Cf. SERRÃO, Joaquim Veríssimo - História de... cit., p. 371. 
um pesado ónus para o orçamento municipal quando, ainda para mais, a Biblioteca era distrital e não concelhia ${ }^{30}$.

Todavia, apesar de definidas as competências e de consumada a inauguração oficial, as especificidades das colecções disponíveis não incentivavam os leitores, cuja concorrência persistia muito limitada. Não obstante as diligências do bibliotecário, avultavam as dificuldades. No reino, não havia quem fizesse a selecção dos livros que este pretendia fossem remetidos do Depósito Geral das Livrarias, ainda que a rainha tivesse dado ordem favorável e que tivessem sido enviadas listas do que existia na Biblioteca e do que se pedia que fosse enviado.

Por conseguinte, em Fevereiro de 1849, Thomas Brown dirigiu um apelativo ofício à Câmara Municipal de Ponta Delgada solicitando autorização e verba para se dirigir a Lisboa e ele próprio fazer a escolha e selecção dos livros de que tanto carecia esta Biblioteca. Dizia ele, com veemência:

"Ponta Delgada já possui uma Biblioteca, mas quase inútil pela sua pobreza. Os despojos dos Mosteiros suprimidos que lhe servirão (sic) de fundo, de modo algum satisfazem as exigências do Público; e este justamente reclama (...)"31.

Atendendo a que outras bibliotecas já beneficiavam de livros do Depósito Geral, questionava-se este bibliotecário porque a de Ponta Delgada também não podia usufruir do mesmo benefício. Existia superior autorização e apenas parecia faltar quem a executasse. Por isso Thomas Brown ofereceu os seus préstimos, solicitando a manutenção do seu salário e a cobertura das despesas com a viagem de ida e volta. Se a frequência da Biblioteca era quase nula, pouca diferença faria a sua ausência por dois ou três meses e, ademais, tudo isto seria compensado ${ }^{32}$.

O bibliotecário partiu mas não mais regressou, decerto por causa das dificuldades financeiras que ensombravam o bom funcionamento da

${ }^{30}$ Por isso, por Decreto de 16 de Fevereiro de 1928, a Biblioteca Pública passou para a tutela da Junta Geral do Distrito de Ponta Delgada que passou então a assegurar todas as despesas. Cf. DIAS, Urbano de Mendonça - Ponta Delgada ... cit., p. 104.

${ }^{31}$ BPARPD - FBPARPD - Série 004, Lv 20, Correspondência Expedida, Ofício dirigido à Câmara Municipal de Ponta Delgada, 7 de Fevereiro de 1849, fl. $5 \mathrm{v}$.

${ }^{32}$ Idem, fl. 6. 
instituição. Por portaria de 27 de Setembro de 1851 e decreto do dia 15 do mesmo mês foi nomeado, como novo bibliotecário, Mariano José Cabral ${ }^{33}$ que se encontrava em Lisboa, mas era de origem micaelense. A Biblioteca estava encerrada desde Março de 1849, ou seja, desde a partida do antecessor, apesar da edilidade ter tentado a reabertura, mas sem a presença de um funcionário habilitado. Aliás, as autoridades municipais haviam tentado, junto da Câmara dos Deputados, conseguir a manutenção da Biblioteca por via da doação da cerca do convento (onde se viria a construir o mercado da cidade) cujos rendimentos abonassem a favor da Câmara e, por consequência, da própria livraria pública ${ }^{34}$.

Mariano José Cabral chegou à ilha a 11 de Outubro de 1851 e logo no dia 13 se apresentou ao Governador Civil que, de imediato, o remeteu à Câmara Municipal. A tomada de posse deu-se no dia 20 e segundo se pode verificar pelas palavras do próprio dirigidas ao Ministério do Reino:

"Tenho a satisfação de poder comunicar a V. Sra., que a minha nomeação agradou geralmente aos micaelenses como se pode ver das folhas públicas desta cidade, tanto políticas como literárias. (...). A Câmara Municipal desta cidade atendendo aos desejos de seus cidadãos, já em 6 de Setembro último tinha aberto a Biblioteca, encarregando a João Jacinto Lopes ${ }^{35}$ o seu cuidado, para que um ou outro estudioso achasse abertas as portas deste tão útil estabelecimento, que agora vai entrar em seu andamento regular" ${ }^{\prime 36}$.

De facto, foi com este bibliotecário que se fez eco na imprensa local dos horários de funcionamento da instituição: no Inverno das dez horas da

${ }^{33}$ Mariano José Cabral nasceu na ilha de S. Miguel e faleceu no Rio de Janeiro em Dezembro de 1877. Quando deixou o cargo de bibliotecário já não seria muito novo, mas partiu para o Brasil, radicando-se no Rio de Janeiro, onde se dedicou à vida jornalística. Foi mesmo um dos redactores da Gazeta de Notícias brasileira. Antes disso, chegou a fundar jornais que se publicaram em Lisboa e outros em S. Miguel. Deixou ainda alguns livros de História dos Açores e de Portugal, biografias e traduções de obras francesas. Cf. DIAS, Urbano de Mendonça - Literatos dos Açores (história), $2^{\mathrm{a}}$ edição, org. de Lúcia Costa Melo, Vila Franca do Campo: Ilha Nova, 2005, p. 595-596.

${ }^{34}$ Cf. BICUDO, Aníbal - Em Louvor ... cit., p. 65.

${ }^{35}$ Segundo Mariano José Cabral, este não tinha quaisquer habilitações literárias e, por isso, passou a contínuo.

${ }^{36}$ BPARPD - FBPARPD - Série 004, Lv 20, Correspondência Expedida, ofício dirigido ao Ministério do Reino a 30 de Outubro de 1951, fl. 7. 
manhã às duas e meia da tarde; no Verão desde as nove até à hora indicada por lei. Foi igualmente com Mariano José Cabral que se passou a elaborar uma relação semanal de todas as obras pedidas diariamente para registo do movimento da casa. Uma cópia da mesma era enviada, com regularidade, ao Conselho Superior da Instrução Pública, em Coimbra. De resto, a própria edilidade concordou em dispensar um oficial amanuense para coadjuvar nas tarefas de catalogação e reposição de livros, uma vez que o novo responsável encontrou 5.029 volumes colocados nas suas estantes, mas sem ordem alguma. Foi ainda solicitada à Biblioteca Nacional uma cópia do respectivo regulamento interno para que servisse de modelo ao de Ponta Delgada ${ }^{37}$. Mariano José Cabral foi ainda obrigado a redigir um novo catálogo das obras e manuscritos da Biblioteca por, segundo ele, não ter encontrado um que estivesse em condições.

Por finais de 1851, a Biblioteca de Ponta Delgada conseguiu recuperar o valioso manuscrito do Padre Agostinho de Mont'Alverne, Crónica da Província de S. João Evangelista, - que trata da história das ilhas dos Açores até 1695 -, o qual se encontrava extraviado nas mãos de um particular ${ }^{38}$. Pela mesma altura foram adquiridas obras como os Ensaios, de José de Torres, A Democracia em França, de Guizot ou colecções de jornais como O Agricultor Micaelense ${ }^{39}$. Iniciativa de relevo do novo bibliotecário foi a de contactar com várias redacções de periódicos do continente a fim de solicitar o envio de números avulsos ou de colecções, com o intuito de manter actualizado o público micaelense. Uma das suas dificuldades, porém, resultou do facto do amanuense prometido pela Câmara nunca ter

${ }^{37}$ Idem, fl. 7v.

${ }^{38}$ A recuperação deste manuscrito ficou a dever-se, e muito, à Sociedade Escolástico Micaelense que, desde muito cedo, solicitou que se procurasse o importante manuscrito do Padre Mont'Alverne, para ser publicado, pois constava que fazia parte da extinta livraria dos Franciscanos. Dizia-se que o Padre Joaquim José Tavares não o entregara na devida altura, pelo que o assunto assumia grande urgência., para que se conseguisse a devida divulgação como contributo para a instrução dos habitantes de Ponta Delgada. De facto, confirmou o bibliotecário que tal manuscrito não se encontrava entre os livros do extinto convento de S. Francisco, nem nos da Conceição, entregues pelo referido padre. Terá sido, pois, Mariano José Cabral quem deu o alerta e passou à acção. BPARPD - FBPARPD - Série 004, Lv 19, ob. cit., Ofício da Sociedade Escolástico Micaelense.

${ }^{39}$ BPARPD - FBPARPD - Série 004, Lv 20, ob. cit., Ofício ao Presidente da Câmara Municipal de Ponta Delgada, 4 de Dezembro de 1851, fls. 10v-11. 
chegado a entrar em funções por sobrecarga de serviço e, por isso, Mariano José Cabral viu-se, a sós, com uma árdua tarefa. Apenas em Junho de 1860 conseguiu completar o primeiro Catálogo Alfabético das obras, opúsculos e manuscritos desta instituição, graças ao seu esforço e empenhamento ${ }^{40}$.

Durante este período, o mesmo bibliotecário também começou a detectar as lacunas já evidenciadas por Thomas Brown. Face ao número de pedidos, tornava-se inadmissível, por exemplo, a inexistência de uma História de Portugal completa. No tocante aos ramos de Belas Artes, Ciências Naturais, Ofícios, Ciências Políticas e Civis, a Biblioteca era "deficientíssima" enquanto excediam as obras de ciências eclesiásticas e canónicas. O problema parecia agigantar-se porque as entidades locais não dispunham de margem orçamental para avultados investimentos nesta área ${ }^{41}$.

Aliás, as questões financeiras e em torno dos recursos humanos ensombraram, desde início, o funcionamento desta instituição. Por um lado, avultavam despesas com ordenados de funcionários, compra de materiais e de estantes, recuperação de livros, limpezas e manutenção. Por outro, escasseavam as verbas destinadas à aquisição de livros.

Tomas Brown Soares tinha um vencimento de $157 \$ 500$ réis, dos quais descontava os devidos direitos de mercê e mais $5 \%$ adicionais $^{42}$. Em finais da década de 50, o vencimento de Mariano José Cabral era já de $300 \$ 000$ réis insulanos anuais, bem como o do seu sucessor. Na última década da centúria, a Biblioteca contava com um bibliotecário designado como director, - neste caso, o Dr. Francisco da Silva Cabral -, persistindo, porém, a grande instabilidade quanto aos contínuos, cujos ordenados rondavam os $72 \$ 000$ réis insulanos. Os três bibliotecários conheceram numerosos funcionários subalternos pois estes ora deixavam o lugar por motivo de doença ou de mudança de residência, ora passavam para outro emprego mais conveniente e melhor remunerado.

${ }^{40}$ BPARPD - FBPARPD - Série 004, Lv 20, ob. cit., Ofício ao Conselheiro Director Geral da Instrucção Pública, 23 de Junho de 1860, fl. 52.

${ }^{41}$ BPARPD - FBPARPD - Série 004, Lv 20, ob. cit., Estatísticas e Ofício ao Governador Civil de Ponta Delgada, 27 de Janeiro de 1852, fls. 14-15.

${ }^{42}$ BPARPD - FBPARPD - Série 004, Lv 19, Correspondência Recebida, Cópia de Ofício do Ministério do Reino, 10 de Fevereiro de 1852. 
Após 9 anos de funções e de muitos constrangimentos, Mariano José Cabral solicitou ao Conselheiro Director Geral da Instrução Pública a sua transferência para a Biblioteca Nacional (ou para qualquer outra repartição pública), quer como reconhecimento dos seus serviços, quer por se sentir estagnar, na medida em que as suas funções passaram a limitar-se à entrega de livros aos leitores. Estava convicto que, em Lisboa, podia prestar mais e melhores serviços. Ademais, a situação financeira da instituição micaelense era de tal ordem que o próprio bibliotecário se via obrigado a cobrir, com os seus rendimentos, despesas de funcionamento ${ }^{43}$, já para não mencionar as sucessivas desinteligências com os contínuos e com a própria Câmara Municipal.

Em Julho de 1861, Mariano José Cabral deixou de ser bibliotecário em Ponta Delgada e porque as suas pretensões não terão sido atendidas, pouco tempo depois, partiu com destino ao Brasil, fixando-se no Rio de Janeiro, onde veio a falecer. O seu substituto, como já referimos, foi Francisco da Silva Cabral que tomou posse em Novembro do mesmo ano, depois do cargo ter sido ocupado interinamente pelo Padre José Nicolau Teixeira de Sousa $^{44}$. Francisco da Silva Cabral depressa se iria confrontar com os mesmos obstáculos do seu antecessor, - entre eles a carência de "maior número de exemplares de obras modernas em todos os ramos de ciências e literatura" - registando, porém, uma frequência de leitores em sentido ascendente ${ }^{45}$. Prosseguiram os trabalhos de encadernação e os esforços de aquisição de espécies, muitas delas obtidas com verbas da Junta Geral do Distrito. À iniciativa deste novo bibliotecário ficou a dever-se ainda a venda de livros repetidos ou truncados, cuja verba obtida, acrescida do subsídio camarário, possibilitou a aquisição do Grande Dicionário Larousse.

${ }^{43}$ BPARPD - FBPARPD - Série 004, Lv 20, ob. cit, Ofícios ao Conselheiro Director Geral da Instrução Pública, 3 de Janeiro de 1861 e 8 de Janeiro de 1861, fls. 62 v e ss.

${ }^{44}$ BPARPD - FBPARPD - Série 004, Lv 20, ob. cit, Ofício ao Presidente da Câmara, 6 de Novembro de 1861, fl. 71.

${ }^{45}$ BPARPD - FBPARPD - Série 004, Lv 20, ob. cit., Carta ao Governo de Sua Majestade, em 30 de Outubro de 1862, fl. 77. 


\section{Aspectos do quotidiano da Biblioteca: das colecções às instalações}

Após a conclusão do catálogo da autoria de Mariano José Cabral, podia confirmar-se que o número de volumes da Biblioteca Pública de Ponta Delgada havia aumentado praticamente para o dobro em relação ao montante inicial, ainda que existissem títulos em duplicado e até quatro ou cinco exemplares de um mesmo livro. Terão vindo algumas obras procedentes de Lisboa, entre elas ofertas de cariz público ou oficial (compêndios, Diários das Cortes, legislação, tratados), para além das aquisições e de muitas doações feitas por particulares, as quais se prolongariam pelo século XX adiante.

Logo em 1854, João Anselmo da Cruz Pimentel Choque deixou em testamento o Journal da Sociedade das Sciências Médicas de Lisboa. Os números em falta deveriam ser pedidos, à redacção, por André António Avelino, reputado médico local que fora director da escola Médico-Cirúrgica de Ponta Delgada ${ }^{46}$. Em finais de 1864, por exemplo, a imprensa micaelense deu eco à doação de 1366 volumes, de diferentes ramos da ciência, por parte do proprietário José do Canto, entre os quais se contava uma grande colecção de gramáticas de diferentes línguas ${ }^{47}$.

Em 1865, conforme se pode observar pela leitura do Quadro I, o número de títulos e de volumes ascendera, respectivamente, a quase 6.300 e a pouco mais de 10.000 , ainda que se mantivesse a enorme clivagem na distribuição dos exemplares pelas áreas do saber. Continuavam a predominar os livros eclesiásticos, seguidos, a considerável distância, pelos de História e de Literatura. Em número bastante inferior estavam os de Matemática, Física e Química, Geografia, Agricultura e, sobretudo, Economia Política e Belas Artes.

${ }^{46}$ BPARPD - FBPARPD - Série 004, Lv 19, ob. cit., Carta do testamenteiro Eusébio Dias Poças Falcão, 30 de Agosto de 1854.

${ }^{47}$ BPARPD - FBPARPD - Série 004, Lv 20, ob. cit., Ofício a José do Canto, 28 de Outubro de 1864, s/ fls. 
Quadro 1 - Mapa Estatístico da Livraria Pública de Ponta Delgada, de 1865, com a sua classificação, número de obras e volumes ${ }^{48}$

\begin{tabular}{|c|c|c|}
\hline Classificação & Obras & Volumes \\
\hline História e Literatura & 1622 & 2133 \\
\hline Ciências Eclesiásticas & 3759 & 6557 \\
\hline Ciências Jurídicas & 360 & 559 \\
\hline Ciências Filosóficas & 298 & 489 \\
\hline Medicina & 98 & 141 \\
\hline Matemática & 66 & 86 \\
\hline Física e Química & 53 & 69 \\
\hline Geografia & 15 & 26 \\
\hline Agricultura & 13 & 26 \\
\hline Economia Política & 3 & 3 \\
\hline Belas Artes & 4 & 4 \\
\hline Soma & 6.291 & 10.093 \\
\hline
\end{tabular}

Todavia, os legados prosseguiram e alguns deles avultados. Anos mais tarde, por exemplo, os herdeiros do Dr. José Afonso Botelho de Andrade da Câmara e Castro, ausentando-se para Lisboa, deixaram à guarda da Biblioteca a sua livraria com mais de sete mil volumes (e respectivas estantes) que representavam "condignamente a literatura deste século"49. Mas, apenas por volta de 1890, o bibliotecário Francisco da Silva Cabral reconhecia que a Biblioteca de Ponta Delgada já incluía uma boa parte das "principais obras, que satisfazem às primeiras exigências dos seus visitantes" 50 .

A trágica morte de Antero de Quental, a 11 de Setembro de 1891, viria antecipar o enriquecimento do acervo desta livraria. O poeta legou à instituição toda a sua biblioteca particular, composta por 782 volumes, muitos deles de "grande qualidade" e em língua alemã, com predomínio para as áreas da Literatura e da História. Por consequência, no primeiro de Janeiro de 1893, por iniciativa da Câmara Municipal, foi inaugurada solenemente a secção com a livraria de Antero, colocada numa estante especial e num recanto ornamentado com o busto em mármore do poeta,

${ }^{48}$ BPARPD - FBPARPD - Série 004, Lv 20, ob. cit., Mapa estatístico, 21 de Junho de $1865, \mathrm{~s} / \mathrm{fl}$.

${ }^{49}$ BPARPD - FBPARPD - Série 004, Lv 19, ob. cit., Cópia da carta da Câmara Municipal, 22 de Dezembro de 1888.

${ }^{50}$ BPARPD - FBPARPD - Série 004, Lv 21 (2), Correspondência Expedida, Relatório de $1889 / 1890$, fls. 9 e ss. 
da autoria de Simões de Almeida. Na sessão, foram oradores Caetano d'Andrade Albuquerque, presidente da Câmara, João Machado de Faria e Maia e o Visconde de Faria e Maia ${ }^{51}$.

Em 1895, outra importante aquisição viria a ter lugar por iniciativa municipal. A Câmara adquiriu para a Biblioteca 900 volumes, isto é, 385 colecções de jornais do arquipélago pela módica quantia de $385 \$ 000$ réis. Havendo números repetidos, considerou o então presidente da edilidade, José Maria Raposo d'Amaral Jr., que podiam ser de grande utilidade em futuras trocas ou substituições ${ }^{52}$.

Paulatinamente, e apesar das adversidades, esta instituição ia cimentando as suas funções civilizacionais e educativas, prestando um relevante serviço público, tanto na guarda e conservação de livros e manuscritos, como no seu empréstimo e divulgação, propiciando hábitos de estudo e de leitura. De acordo com o respectivo regulamento ${ }^{53}$, abria todos os dias não santificados ou feriados, das 9 h00 às $13 \mathrm{~h} 00$. A leitura era presencial, sendo proibido mexer nos livros sem autorização ou ler em voz alta. Cabia ao bibliotecário o controlo dos empréstimos e das leituras e ao contínuo, além dos serviços normais, a limpeza da sala e das estantes. Se alguns dos problemas iniciais pareciam estar ultrapassados, estabelecendo-se a normalidade do funcionamento, por outro lado a questão das instalações ia-se agravando.

Não obstante o salão da Biblioteca servir de palco a conferências, reuniões, saraus literários e até a concertos beneficentes ${ }^{54}$, as acomodações eram assaz deficitárias porque partilhadas com o Liceu da cidade, sito ao Convento da Graça. Com o passar dos anos e o aumento do número de livros, o espaço tornara-se demasiado exíguo. Por vezes, ocorriam ajustamentos que se tornavam muito incómodos. Havendo, por exemplo, necessidade de instalar a secretaria do estabelecimento de ensino no quarto do bibliotecário, foi este obrigado a mudar-se para outro compartimento, por ordem do

${ }^{51}$ BPARPD - FBPARPD - Série 004, Lv 21 (3), Correspondência Expedida, Relatório de 1893 , fls. 31 e ss.

${ }^{52}$ Idem, Ofício da Câmara Municipal, 21 de Dezembro de 1895.

${ }^{53}$ Regulamento de 2 de Janeiro de 1864.

${ }^{54}$ A 5 de Abril de 1858, por exemplo, ocorreu um concerto em benefício da Sociedade dos Amigos das Letras e das Artes. BPARPD - FBPARPD - Série 004, Lv 19, ob. cit., Ofício da Câmara Municipal, 22 de Março de 1858. 
Governo Civi155. Já em 1864, o então bibliotecário em funções entendia que pelo facto da sala de leitura se achar no interior do edifício do Liceu, constituía um motivo de redução do público. Achava por demais necessário que se construísse, sem grandes gastos, uma pequena sala contígua, mas virada à rua, de modo a promover uma maior curiosidade a par de uma mais fácil acessibilidade ${ }^{56}$.

Se as instalações contíguas ao Liceu eram prejudiciais à Biblioteca Pública, por outro lado, esta circunstância também não agradava aos responsáveis pela instituição de ensino. Em 1889 o conselho directivo da mesma enviou uma carta ao Presidente da Câmara a queixar-se do muito barulho que era constante nas salas da livraria municipal e que muito prejudicava o ambiente das aulas. O próprio reitor havia presenciado o que designava como "espectáculo impróprio de uma biblioteca" que, por essência, devia ser um lugar de silêncio, dedicado ao estudo e à leitura. Alertava, pois, o mesmo professor que urgia encontrar novas instalações para a Biblioteca - mais afastadas, ainda que acessíveis - aproveitando-se aquele espaço somente para a vida escolar. A Biblioteca tornara-se um "elemento de indisciplina" porque estava "sendo um refúgio dos estudantes que não querem ir às aulas e de divertimento para muitos" 57 .

Por fim, e possivelmente por denúncia do bibliotecário, solicitou o Reitor (na altura Eugénio Vaz Pacheco do Canto e Castro), e por mais de uma vez, o nome de todos os estudantes perturbadores do sossego da Biblioteca Pública a fim de serem tomadas as devidas providências. Não muito tempo depois, o Ministério das Obras Públicas entendia dever proceder-se à transferência desta instituição para um lugar mais apropriado, ficando aquela sala destinada ao Museu de História Natural que, entretanto, ia progredindo em número de peças e colecções ${ }^{58}$.

${ }^{55}$ Idem, 3 de Março de 1852.

${ }^{56}$ BPARPD - FBPARPD - Série 004, Lv 20, ob. cit., Relatório, 17 de Outubro de 1864, s/ fls.

${ }^{57}$ BPARPD - FBPARPD - Série 004, Lv 19, ob. cit., Ofício do Reitor do Liceu, 10 de Maio de 1889.

${ }^{58}$ BPARPD - FBPARPD - Série 004, Lv 21 (3), Correspondência Expedida, Relatório de 1891 , fl. $11 \mathrm{v}$. 
Apesar dos esforços de alguns responsáveis, a Biblioteca tornou-se alvo do espírito contestatário dos republicanos. O recém formado Centro Republicano de Ponta Delgada não se coibiu de criticar as normas de funcionamento através do seu órgão A República Federal que narra assim, num pequeno artigo:

"Este estabelecimento muito grande e com muitos livros velhos, tratados de teologia, quase todos em latim, apenas se abre das 10 às 2 horas do dia em dias não feriados. Os estudantes do liceu são quase os únicos frequentadores da biblioteca, para consultar algum dicionário, menos o de "Bouillet" porque ela o não possui. Como pela nova reforma da instrução secundária, também funciona o liceu às quintas feiras, e que não funcionasse, era um dia mais próprio para os alunos consultarem livros, achamos que o senhor bibliotecário, como pessoa de escrúpulos, devia abrir a biblioteca também às quintas-feiras, embora o regulamento o não obrigue, ou mandar o seu contínuo, prestando assim um serviço ao público, e fazendo jus ao ordenado do seu emprego bem parecido com uma conesia"s9.

Pelas palavras do periódico pode-se inferir que, no último quartel da centúria, o regulamento de 1864 sofrera algumas alterações ou quiçá alguns atropelos uma vez que, segundo o jornal, a Biblioteca deixara de abrir às quintas-feiras e o seu horário passara a ser das $10 \mathrm{~h}$ às $14 \mathrm{~h}$. Outra crítica a este estabelecimento relacionava-se com o prolongado período de encerramento por férias dos funcionários. Nada mais, nada menos, que os dois meses de Agosto e Setembro. Além de ser excessivo, afigurava-se cada vez mais desadequado quando, pela nova legislação, os alunos liceais passavam a ter exames em Outubro. Ademais, na época estival os estudantes poderiam ler as obras para as quais não tinham tempo durante o período lectivo. Sugeriam então os redactores do órgão republicano, chamando a atenção da Câmara Municipal, que se admitissem mais empregados de modo a alargar o horário de funcionamento da Biblioteca Pública ${ }^{60}$.

Apesar de não terem sido atendidas de imediato, afigura-se que as críticas republicanas não terão sido totalmente em vão. A partir de 1892 o bibliotecário e director Francisco da Silva Cabral passou a ter um auxiliar,

\footnotetext{
${ }^{59}$ A República Federal, no 6, 24 de Maio de 1881.

${ }^{60}$ A República Federal, no 24, 4 de Outubro de 1881.
} 
o qual, alguns anos mais tarde, ocuparia o seu lugar. A 9 de Junho de 1897, Alexandre de Sousa Alvim, provido pelo decreto de 17 de Maio do mesmo ano, deixou de ser auxiliar e passou a bibliotecário devido à aposentação do seu antecessor, por motivos de segurança e disciplina. Silva Cabral, que chegou a completar 35 anos de serviço, deixara de ser respeitado pelos jovens leitores, em virtude da sua avançada idade, e muitos livros começaram a surgir com mutilações e estragos ${ }^{61}$. Por consequência, uma das primeiras medidas de Sousa Alvim foi a de acabar com o empréstimo de livros raros. Por outro lado, tomou a iniciativa de publicar um boletim mensal ${ }^{62}$ e ainda assumiu a responsabilidade de receber e cuidar da imensa doação póstuma da biblioteca de Ernesto do Canto ${ }^{63}$.

Falecido em Agosto de 1900, este próspero proprietário, influente cidadão e curioso historiador legou toda a sua livraria, composta por cerca de $5 \mathrm{mil}$ volumes e respectivas estantes, à Biblioteca Pública de Ponta Delgada. A dimensão deste legado veio agudizar ainda mais o problema das instalações, forçando a Câmara Municipal a tomar medidas com o apoio do Governo Civil. Uma vez que a casa, paredes meias com o edifício da Biblioteca, pertencia ao Ministério das Obras Públicas e estava emprestada ao município para que ali funcionasse uma escola do sexo feminino, o governador civil, Francisco d'Andrade Albuquerque resolveu interceder

${ }^{61}$ Série 004, Lv 21 (2), Correspondência Expedida, Ofício no 14, 9 de Junho de 1897, fl. $23 \mathrm{v}$ e Ofício $\mathrm{n}^{\circ} 18,30$ de Junho de 1897 , fls. $24 \mathrm{v}$ e ss.

${ }^{62}$ Série 004, Lv 21 (2), Correspondência Expedida, Relatório de 30 de Outubro de 1897, fls. $29 \mathrm{v}$ e ss.

${ }^{63}$ Filho do rico morgado José Caetano Dias do Canto e Medeiros, formou-se em Filosofia, em 1856, na Universidade de Coimbra. Fixou-se na sua cidade natal, Ponta Delgada, dedicando-se aos negócios familiares e à investigação histórica. Esta paixão levou-o a adquirir numerosa bibliografia referente ao arquipélago, coleccionando também documentos e opúsculos raros, que adquiriu no continente ou no estrangeiro, e lhe permitiram publicar o Arquivo dos Açores. Entre os cargos públicos que desempenhou, conta-se a presidência da primeira Junta Geral do Distrito Autónomo de Ponta Delgada, bem como os lugares de vereador da Câmara Municipal e provedor da Misericórdia local. Integrou ainda inúmeras comissões de beneficência e instrução e foi sócio da Academia das Ciências e da Sociedade de Geografia de Lisboa. Deixou algumas obras da sua autoria, como "Quem deu nome ao Labrador?", in Arquivo dos Açores, vol. II; Centenário da Descoberta da América por Cristóvão Colombo (1492-1892), Ponta Delgada, Tip. do Arquivo dos Açores, 1892. Cf. DIAS, Urbano de Mendonça-Literatos dos ... cit., pp. 102-110. Veja-se: TOMÉ, Teresa - Ernesto do Canto: os Açores na problemática da cultura do século XIX, Ponta Delgada: Signo, 1989. 
junto da Direcção Geral das Obras Públicas, para que atenta a contiguidade das edificações se abrisse, de imediato, uma comunicação interior com rapidez e pouca despesa. Depois, procurou que fosse cedida a mesma casa à edilidade de forma a ampliar as instalações da Biblioteca, enquanto não fosse possível obter edifício próprio. Entre os argumentos esgrimidos estavam o facto de considerar que não seria complicado adquirir outras instalações para a escola feminina e, sobretudo, as dificuldades sentidas no acesso às instalações da Biblioteca, através do Liceu, quando na nova casa este seria bem mais facilitado. Por fim, considerando que todas as entidades locais se encontravam de acordo, entendia que a Direcção Geral das Obras Públicas prestaria um grande serviço à cidade de Ponta Delgada, pois tratava-se de um significativo melhoramento material e cultural ${ }^{64}$.

A solicitação do governador civil foi atendida. Por ofício de 5 de Dezembro de 1900, a Direcção Geral das Obras Públicas autorizou a cedência da casa da escola do sexo feminino da freguesia de S. Pedro ao município micaelense, para ampliação da Biblioteca Pública, considerando a exiguidade das instalações que comportavam, a esta data, cerca de 14.000 volumes. Para os devidos efeitos, foi então solicitado ao director das obras públicas do distrito o respectivo projecto e orçamento ${ }^{65}$. Em 1902, o secretário do Governo Civil, Jacinto de Teves Adam, rogava ao respectivo Ministro e Secretário de Estado as mais urgentes diligências no sentido de autorizar não apenas o projecto e o orçamento enviados pelo director distrital, mas o início das obras do edifício anexo à livraria pública, uma vez que era de suma necessidade ali colocar os livros e as estantes legadas por Ernesto do Canto ${ }^{6}$.

Afinal, a doação deste ilustre micaelense, que representara um elevado e precioso contributo para o público leitor da cidade, também correspondeu a uma significativa fonte de receitas. Nos anos subsequentes, Alexandre de Sousa Alvim registou não apenas as despesas com a conservação deste

${ }^{64}$ BPARPD - FGCPD (Fundo do Governo Civil de Ponta Delgada), Ofício no ${ }^{58}$, Obras Públicas, 29 de Outubro de 1900, Livro 223, Correspondência dirigida a Diversas Secretarias de Estado, 1897-1902, fls. 33-33v.

${ }^{65}$ BPARPD - FGCPD, Livro 223, ob. cit., Ofício no 4, Ministro das Obras Públicas, Comércio e Indústria, 23 de Janeiro de 1901, fls. 37-37v.

${ }^{66}$ BPARPD - FGCPD, Idem, Ofício n ${ }^{\circ}$ 6, Ministro e Secretario de Estado dos Negócios das Obras Públicas, Comércio e Indústria, 1902, fl. 50v. 
legado, em conformidade com o respectivo testamento, mas também os proventos retirados da venda de volumes do Arquivo dos Açores - compilação de documentos sobre a história das ilhas feita por Ernesto do Canto - e de outras publicações suas. Além de numerosos volumes do Arquivo - só a 15 de Setembro de 1904, por exemplo, foram vendidos 200 da $2^{\circ}$ edição do ${ }^{\circ}$ VI - eram também vendidos exemplares da Biblioteca Açoriana, da obra sobre Os Corte-Reais, do Tratado das Ilhas Novas, assim como do Ensaio Bibliográfico e ainda do ensaio sobre o Centenário do Infante D. Henrique ${ }^{67}$. Entre Janeiro de 1901 e Outubro de 1926, não obstante as avultadas reparações ou aquisições de estantes, bem como diferentes trabalhos de encadernação, o saldo acumulado a favor da Biblioteca foi de $1.930 \$ 83$ réis, graças à cívica generosidade de Ernesto do Canto.

A implantação da República, em 1910, teria também consequências para a história e o funcionamento desta instituição. A extinção do Tribunal da Relação dos Açores e da respectiva Procuradoria, ordenadas pelo Governo Provisório por decreto de 30 de Novembro daquele mesmo ano, levou a que o Ministério da Justiça ordenasse que, uma parte da documentação pertencente a este órgão, fosse depositada na Biblioteca Pública de Ponta Delgada. Por conseguinte, foi nomeada uma comissão composta por Rodrigo Rodrigues, oficial da Repartição da Fazenda, José Pedro Costa, professor aposentado do Liceu e pelo próprio bibliotecário, Alexandre de Sousa Alvim, com o intuito de proceder à respectiva inventariação. A esta comissão vieram a ser agregados os cidadãos Guilherme Frazão e António Joaquim Arruda com a finalidade de a auxiliarem no referido inventário, atendendo ao elevado número de processos e demais documentação existente. Os móveis, os utensílios e a legislação ficaram ao dispor do Delegado da República e do Juiz de Direito da Comarca de Ponta Delgada que, por seu turno, passaram a ocupar os gabinetes do Presidente e do Secretário do extinto Tribunal ${ }^{68}$.

A supressão deste órgão judicial deixou sem emprego Nicolau Martins de Bettencourt, Clemente Peixoto de Mendonça, Francisco do Rego Silva Pontes e José Augusto Borges do Canto Pontes, este último funcionário da

${ }^{67}$ BPARPD - FBPARPD, Dep. 21, nº 6, Livro n ${ }^{\circ} 1$, Arquivo dos Açores, etc. Corrente.

${ }^{68}$ BPARPD - FGCPD, Livro 328, Correspondência dirigida pela $1^{a}$ Repartição deste Governo Civil às diversas Autoridades e Pessoas, 1906/1911, fls. 93 e 95v. 
extinta Procuradoria Régia. Para obstar a este problema, o recém-nomeado governador civil, Francisco Luís Tavares decidiu colocar, provisoriamente, os três primeiros elementos a colaborar na classificação dos processos e dos documentos do extinto arquivo e o último ao serviço da Biblioteca Pública da cidade, reforçando assim o corpo de funcionários ${ }^{69}$.

Pelo decreto de 16 de Fevereiro de 1928 (art. ${ }^{\circ}$ 34) as despesas desta instituição passaram para a responsabilidade da Junta Geral do Distrito ${ }^{70}$ que, aliás, assumiu nesta altura inúmeros encargos. Sob a presidência de Luís de Bettencourt, a Junta Geral não só passou a superintender a administração da Biblioteca, como assegurou a limpeza e a manutenção de muitos livros. No intuito de a valorizar ainda mais, fez adquirir todo o espólio de Teófilo Braga constituído por 8.000 volumes de várias obras, bem como por milhares de cartas e manuscritos ${ }^{71}$.

Em 1931, por via do Decreto-Lei n ${ }^{0} 20.484$, de 6 de Novembro ${ }^{72}$ procedeu- $^{-}$ -se a uma remodelação do quadro de pessoal e dos respectivos serviços, sendo transferidas definitivamente para a Junta Geral as competências até aí exercidas pela Câmara Municipal. Todavia, estas competências foram limitadas apenas aos encargos com os funcionários e o funcionamento, pois a instituição passou a estar subordinada à Inspecção Geral das Bibliotecas e Arquivos, reservando-se, pois, à Junta uma intervenção de cariz administrativo. Com este diploma foi criado, pela primeira vez, um Arquivo Distrital para funcionar em anexo à Biblioteca Pública, em moldes muitos semelhantes aos das congéneres de Braga, Leiria e Évora. Deste modo, transitaram para as respectivas instalações os acervos provenientes de cartórios eclesiásticos, registos paroquiais e notariais de todo o Distrito, bem como documentação existente na Direcção e Repartição de Finanças,

${ }^{69}$ BPARPD - FGCPD, Livro 376, Registo da Correspondência dirigida pela $1^{a}$ Repartição às diversas Secretarias d'Estado, 1910-1911, fls. 7v e 8.

${ }^{70}$ DIAS, Urbano de Mendonça - Ponta Delgada ... cit., p. 104.

${ }^{71} \mathrm{O}$ inestimável valor da livraria e da documentação pessoal de Teófilo Braga conferiu a esta aquisição uma importância imensa, então louvada e reconhecida por importantes vultos como o director da Biblioteca da Ajuda, o conservador da Torre do Tombo e o conservador da Biblioteca Nacional. Cf. BICUDO, Aníbal - Em Louvor ... cit., p. 67.

${ }^{72}$ Publicado no Diário do Governo, I Série, no 258, de 7 de Novembro de 1931. Cf. PAVÃO, Prof. Dr. Almeida - Biblioteca Pública e Arquivo de Ponta Delgada, Separata da Revista Insulana, Ponta Delgada, 1992, p. 270. 
processos cíveis, crime e orfanológicos findos e outros de repartições ou serviços extintos ${ }^{73}$.

Doravante, o quadro desta instituição passou a ser composto por um conservador e um sub-conservador - ambos com habilitações académicas e nomeados pelo governo - e ainda um contínuo e um servente, nomeados pela Junta Geral ${ }^{74}$.

Somente a 18 de Abril de 1941, e após demoradas obras, foi inaugurado o novo edifício da então Biblioteca Pública e Arquivo Distrital de Ponta Delgada, sito à Rua Ernesto do Canto, no qual esta se manteve até finais do século XX. Aqui passaram a funcionar a Sala de Leitura e outros serviços, enquanto os depósitos das livrarias e do arquivo persistiram no edifício do Convento da Graça ${ }^{75}$. Na sessão solene tomaram a palavra o presidente da Junta Geral, bem como o respectivo bibliotecário que então era João de Simas. Por esta altura, era considerável o acervo da instituição. De acordo com Aníbal Bicudo existiam "cerca de 25.000 volumes além de 50.000 processos, 7.627 testamentos, e 1.381 livros de notas, que se encontravam depositados no arquivo da extinta Relação dos Açores" "76. Todavia, dignas de registo eram, de facto, as doações de particulares, entre eles Antero de Quental, Ernesto e Eugénio do Canto, Bruno Tavares Carreiro, o Marquês de Jácome Correa, o Conde dos Fenais, o coronel João Maria de Aguiar e José Bensaúde ${ }^{77}$. Entre 1914 e 1919, Jácome Correia havia ofertado a verba mensal de $50 \$ 00$ com a qual se haviam adquirido cerca de 2.500 volumes $^{78}$. Em 1950, António Borges Coutinho Sousa Dias da Câmara, $3^{\circ}$ Marquês da Praia e Monforte, viria a doar o original das Saudades da Terra de Gaspar Frutuoso ${ }^{79}$.

Desde modo e não obstante as inúmeras carências da Biblioteca Pública de Ponta Delgada - que se confrontava com grandes dificuldades de

${ }^{73}$ Idem, pp. 270-271.

${ }^{74}$ Ibidem, p. 271.

${ }^{75}$ Cf. DIAS, Urbano de Mendonça - Ponta Delgada ... cit., p. 105. Veja-se também SILVEIRA, Francisco da - "Biblioteca Pública e Arquivo de Ponta Delgada" in Enciclopédia Açoriana, www.culturaacores.azores.gov.pt/ea/pesquisa.

${ }^{76}$ BICUDO, Aníbal - Em Louvor ... cit., p. 65-66.

${ }^{77}$ DIAS, Urbano de Mendonça - Ponta Delgada ... cit., p. 103 e 104-105.

${ }^{78}$ BICUDO, Aníbal - Em Louvor ... ob. cit., p. 66.

${ }^{79}$ www.culturaacores.azores.gov.pt/enciclopedia açoriana. 
arrumação e de conservação das espécies - mantinha-se o desiderato da missão institucional de contribuir para o desenvolvimento do nível sócio-cultural da população. Ademais, graças aos esforços de algumas autoridades e, sobretudo, de particulares, por meados do século XX, esta livraria estava classificada como a "quarta entre as bibliotecas eruditas do país"80. Já em 1892, segundo dados do Anuário Estatístico de Portugal, a biblioteca pública micaelense situava-se em $5^{\circ}$ lugar no raking nacional, em função do número anual de leitores. Contra os 36.330 da Biblioteca Nacional de Lisboa, que ocupava o primeiro lugar, a instituição de Ponta Delgada contava com uma média de 1.802, muito acima das de Braga, Évora e Guarda ${ }^{81}$.

\section{As leituras e o público leitor}

Desde inícios do funcionamento deste estabelecimento, a maior parte dos leitores eram alunos do Liceu Nacional, exigindo-se, também por isso, a compra de livros modernos e de compêndios. Mariano José Cabral, enquanto foi bibliotecário, consultava, por vezes, o Comissário dos Estudos ou o Conselho do Liceu para que lhe indicassem títulos de obras mais necessárias ou urgentes. No entanto, para além dos estudantes, também frequentavam a Biblioteca alguns funcionários públicos e estrangeiros ${ }^{82}$, de entre os muitos que visitavam as ilhas ao longo de oitocentos.

Porém, como já referimos, a escassez de verbas e a demora das autorizações para qualquer aquisição constituíam obstáculos imensos à actualização e ao enriquecimento da Biblioteca, motivando insistentes pedidos, por parte do bibliotecário, inclusive aos deputados eleitos pelo Distrito. Outro óbice residia na excessiva demora da chegada dos livros que eram encomendados em Lisboa ou da satisfação dos legados e doações por intermédio dos testamenteiros. Sendo assim, não seria de estranhar o enorme desfasamento da Biblioteca de Ponta Delgada em relação às suas

\footnotetext{
${ }^{80}$ BICUDO, Aníbal - Em Louvor ... cit., p. 67.

${ }^{81}$ TORGAL, Luís Reis e VARGUES, Isabel Nobre - "Espaços de ... cit.", p. 688-689.

${ }^{82}$ BPARPD - FBPARPD, Série 004, Lv 20, Correspondencia Expedida, ofício ao Comissário dos Estudos, 13 de Março de 1852, fl. 16v.
} 
congéneres de Lisboa e do Porto ${ }^{83} \mathrm{o}$ que talvez motivasse o número não muito elevado de requisições. Porém, sem nos atermos à realidade demográfica, outros motivos pareciam justificar a baixa frequência de leitores.

No decurso das décadas de 60 e 70 o bibliotecário Francisco da Silva Cabral além de apontar a escassez de livros modernos, atribuía as oscilações de frequência ao excessivo rigor do regulamento da Biblioteca, uma vez que se tornava bastante incompatível com os horários dos alunos do Liceu e que eram, como já referimos, a principal clientela ${ }^{84}$.

$\mathrm{O}$ quadro que se segue apresenta um balanço do número de requisições feitas, mensalmente, entre 1861 e 1865.

Quadro nº 2 - Requisições feitas na Biblioteca Pública de Ponta Delgada entre 1861 e $1865^{85}$

\begin{tabular}{|c|c|c|c|c|c|}
\hline & 1861 & 1862 & 1863 & 1864 & 1865 \\
\hline Janeiro & 28 & 95 & 28 & 95 & 73 \\
\hline Fevereiro & 18 & 132 & 22 & 66 & 116 \\
\hline Março & 17 & 121 & 46 & 46 & 167 \\
\hline Abril & 42 & 71 & 39 & 78 & 78 \\
\hline Maio & 17 & 122 & 48 & 69 & 147 \\
\hline Junho & 9 & 78 & 41 & 64 & 74 \\
\hline Julho & 102 & 36 & 25 & 16 & 68 \\
\hline Agosto & 38 & 4 & 1 & 0 & 0 \\
\hline Setembro & 0 & 1 & 1 & 1 & 2 \\
\hline Outubro & 74 & 91 & 63 & 110 & 90 \\
\hline Novembro & 78 & 85 & 60 & 103 & 122 \\
\hline Dezembro & 46 & 55 & 30 & 68 & 89 \\
\hline Totais & 469 & 891 & 404 & 716 & 1026 \\
\hline
\end{tabular}

Pela análise do quadro anterior $\left(\mathrm{n}^{\mathrm{o}} 2\right)$ - e comparativamente com o seguinte $\left(\mathrm{n}^{\circ} 3\right)$ - pode dizer-se que, volvidos mais de 12 anos da sua inauguração, a frequência da Biblioteca Pública era pouco elevada. Exceptuando esporádicos meses em que as requisições ultrapassavam a

${ }^{83}$ Idem, fls. 38v-39.

${ }^{84}$ BPARPD - FBPARPD, Série 004, Lv 20, Correspondência Expedida, Relatório, 17 de Outubro de 1864, s/ fls.

${ }^{85}$ BPARPD - FBPARPD, Livro $n^{\circ} 1$, Frequências. Não foi possível recolher os dados do ano de 1860 porque não estava completo. Pressupõe-se a existência de um livro anterior, cujo paradeiro é desconhecido. 
fasquia dos 100, no geral os pedidos oscilavam entre as quatro e as seis ou sete dezenas, quando não eram inferiores. A tendência ascendente verifica-se, sobretudo, a partir de 1863 em que os totais anuais passam de 404, para 716 e 1026, respectivamente, em 1864 e 1865.

Sendo certo que havia dias em que não comparecia qualquer leitor (como em onze dias sucessivos do mês de Fevereiro de 1861), a fraca afluência, durante o período em apreço, era agravada pelas ausências do próprio bibliotecário, na altura Mariano José Cabral. Só no mês de Janeiro de 1861, por exemplo, registamos seis dias em que o mesmo refere os padecimentos que o impediram de se manter no seu posto de trabalho, entre eles, dores de cabeça e de garganta que chegaram a motivar a chamada do médico ${ }^{86}$. Por outro lado, convém não esquecer o avultado número de dias santificados, de Grande Gala (aniversários régios) ou de nojo por falecimento de algum membro da família real e que levavam, como é evidente, ao encerramento das instalações.

De resto, e como nos é dado observar no quadro, no período estival (Agosto e Setembro) as requisições eram quase nulas. Não só os estudantes estavam em gozo de férias, como as do bibliotecário decorriam entre 15 de Agosto e 15 de Setembro, ainda que na segunda quinzena deste mês a frequência persistisse irrelevante. Em Dezembro voltavam a registar-se as férias do Natal, precisamente entre 23/24 de Dezembro e 6 de Janeiro, o que ditava, de novo, o encerramento da Biblioteca.

Entre o conjunto das requisições feitas neste lapso de tempo (por vezes mais do que uma por leitor) deparamos com a consulta de jornais nacionais ou locais (mais antigos ou ainda em publicação), de almanaques, de Diários do Governo ou das Câmaras, de legislação diversa e de estatutos avulsos. Alguns estudos específicos, como Princípios de Política Económica surgem entre os registos, mas o que avultava eram as requisições de dicionários, tais como: Dicionário Franco-Protuguês, Dicionários de Inglês, Dicionário Histórico, Dicionário Geográfico, Magnum Lexicon, Dicionário Bescherelle, Dicionário Latino, Dicionário de Morais, Dicionário de Grego, Dicionários das Invenções, entre outros.

${ }^{86}$ BPARPD - FBPARPD, Livro n ${ }^{\circ} 1$, Frequências...cit., fls. 5, 6, 7. 
Todavia, assumia capital importância, entre as escolhas dos leitores, a literatura portuguesa. $\mathrm{O}$ romance, $\mathrm{o}$ drama e a poesia eram géneros muito requisitados. Desde logo, a poesia camoniana de Os Lusíadas, os poemas de Almeida Garrett (Camões, Retrato de Vénus e D. Branca) ou as primeiras e juvenis composições poéticas que Teófilo Braga publicou, em 1859, intituladas Folhas Verdes.

Dos romances garrettianos destacavam-se O Arco de Santana, Viagens na Minha Terra, Frei Luís de Sousa, O Alfageme de Santarém ou, ainda, a comédia A Sobrinha do Marquês e o Cancioneiro Geral. De Camilo Castelo Branco salientavam-se: A Filha do Arcediago, A Neta do Arcediago, Cenas Contemporâneas, Lágrimas Abençoadas, O Livro Negro de Padre Diniz, Um Homem de Brios e o muito apreciado O Que Fazem as Mulheres. Ainda no âmbito da literatura portuguesa requisitavam-se as peças de teatro de José da Silva Mendes Leal, Os Dois Renegados, Os Homens de Mármore e A Pobreza Envergonhada. De Alexandre Herculano O Monge de Cister, de António Feliciano de Castilho, Amor e Melancolia ou A Novíssima Heloísa, do dramaturgo e historiador Luís Rebelo da Silva, Ódio Velho não Cansa.

Entre a diminuta literatura estrangeira contavam-se as obras francesas O Génio do Cristianismo, de Chateaubriand, As Aventuras de Telémaco de Fénelon e os clássicos de Homero, Horácio e Virgílio. Entre a literatura de viagens destacava-se o relato Viagens de Lisboa à China e da China a Lisboa. Acresciam a esta lista os livros de História ou de cariz biográfico, como: História de Portugal, História da Inquisição, História Eclesiástica, História Universal, História Insulana do Padre António Cordeiro, Anais da Ilha Terceira, História dos Judeus, História da Guerra do Oriente, Portugal e a Casa de Bragança, D. João de Castro, A Mocidade de D. João V, Vida de Frei Batolomeu dos Mártires, Crónica do Conde D. Henrique, Crónicas da Província de S. João Evangelista do Frei Agostinho de Mont'Alverne, Filipa de Vilhena, Os Portugueses em África, Memórias sobre o Terramoto em Lisboa e isto sem descurar diversos livros de teologia, incluindo Sermões do Padre António Vieira e a própria Bíblia Sagrada.

Em suma, a avultada consulta de dicionários, de livros de História e de literatura portuguesa e ainda de compêndios de Filosofia, de Aritmética, de Álgebra, Geometria, Lógica e Gramática, acrescidos dos atlas (Atlas 
Moderno ou Novo Atlas) comprova a maioritária frequência de jovens alunos de Colégios e do Liceu da cidade. No entanto, há outros dados interessantes que se recolhem da leitura dos nomes dos leitores deste período.

Em primeiro lugar, a gritante ausência de mulheres. A Biblioteca integrava os círculos masculinos e estudantis, persistindo a leitura feminina - quando existia - no recato do lar e circunscrita aos livros tidos como aconselháveis ao "sexo frágil". No geral, até meados do século XX, considerava-se que os romances e as novelas exerciam um efeito nefasto sobre as mulheres. Paradoxalmente, a designada literatura "cor-de-rosa", destinada ao público feminino, era tida como uma diversão perigosa e muito pouco instrutiva e moralizadora ${ }^{87}$. Como refere Irene Vaquinhas apesar das transformações sociais em curso "insistia-se numa visão passadista da mulher, como um ser frágil, dependente e incompleto, incapaz de resistir às tentações do romance". Será entre alguns autores de "filiação republicana" que se começará a defender posições contrárias e até o carácter pedagógico do romance ${ }^{88}$.

Em segundo lugar, no seio deste universo jovem, também se incluíam adultos, alguns deles figuras de relevo e da elite social local, detentores até de cargos públicos ${ }^{89}$ ou ligados à escrita e ao jornalismo ${ }^{90}$. Militares e padres também frequentavam a sala de leitura ${ }^{91}$, assim como médicos e juízes da

${ }^{87}$ Veja-se VAQUINHAS, Irene - "Perigos da leitura no feminino. Dos livros proibidos aos aconselhados (séculos XIX-XX)", in Ler História, 59 (2010), 83 e ss.

${ }^{88}$ Idem, p. 91.

89 António Pacheco do Amaral, Francisco de Medeiros Borges, António Joaquim Nunes de Vasconcelos, Frederico Augusto Serpa, João Machado de Faria e Maia, Francisco António Jácome Correia, Manuel José da Rocha, Manuel António Sequeira, André Diogo Martins Pamplona Corte-Real, Amaro Augusto Serpa, Carlos Botelho de Melo, João Velho Quintanilha, João de Medeiros Frazão, Fortunato Zagury, Pedro Vaz Pacheco de Castro e André Vaz Pacheco da Castro, Isaac Benjamim, Lindorff Portugal Lima, António de Medeiros Galvão, Dr. Eugénio do Canto, Dr. João Soares de Albergaria.

${ }^{90}$ Por exemplo, Francisco Maria Supico.

${ }^{91}$ Tenente Coronel José Soares de Albergaria e os padres Augusto Carlos de Melo, António Jacinto de Melo, Jacinto Manuel da Costa, Manuel Pacheco de Medeiros, Januário Filomeno Veloso, Manuel César de Oliveira, Bento José Pacheco, Júlio de Melo, Francisco da Silva, Manuel Jacinto de Amaral Botelho. 
Relação dos Açores ${ }^{92}$. Por exemplo, a par do jovem Teófilo Braga ${ }^{93}$, seu pai Joaquim Manuel Fernandes Braga, também era leitor da Biblioteca Pública de Ponta Delgada.

Este conspecto sociológico parece corroborar as afirmações de Maria de Fátima Nunes, quando diz que no período que medeia entre 1820 e 1851 o fenómeno leitura foi-se alargando a um âmbito que ultrapassou, definitivamente, o simples gosto literário. Muitos dos grupos políticos e culturais formaram-se através da leitura e da interiorização de ideários novos que ajudaram a consolidar o "horizonte mental" da burguesia liberal. A imprensa, as obras nacionais e estrangeiras, de variada temática, constituíram círculos de formação e informação cada vez mais amplos e alargados ${ }^{94}$. Por outro lado, a leitura mais eclética, caracterizada pelo romance, a novela, a obra histórica, os relatos de viagens tiveram um amplo e ávido público consumidor. Se os círculos femininos saciavam a sua procura nos gabinetes de leitura que praticavam o empréstimo domiciliário ${ }^{95}$, alguns círculos masculinos, sobretudo os mais jovens, dirigiam-se às bibliotecas públicas.

Já no século XX, manter-se-iam o mesmo núcleo de leitores e idênticas leituras? O quadro $\mathrm{n}^{\circ} 3$, à semelhança do anterior, apresenta o número de requisições feitas na Biblioteca, mensalmente, mas entre os anos de 1926 e 1930.

${ }^{92}$ Os médicos André António Avelino (que foi director da Escola Médico-Cirúrgica de Ponta Delgada) e António Rodrigues da Paz e os desembargadores Motta e Lima.

${ }^{93}$ Encontramos vários registos em seu nome. A 3 de Dezembro de 1860, requisitou várias obras, entre elas $O$ Verdadeiro Método de Estudar e Dante. A 28 de Janeiro de 1861, escolhia Lucrecia e outros romances e a 6 de Fevereiro de 1861 requisitou O Monge de Cister, D. Branca e o Dicionário de Morais. A 1 do mesmo mês havia requisitado o Dicionário Histórico. BPARPD - FBPARPD, Série 001, Lv 1, fls. 4 e 6.

${ }^{94}$ NUNES, Maria de Fátima Nunes - "A leitura política, económica e mundana", in REIS, António, dir. - Portugal Contemporâneo, 1820-1851, Lisboa: Alfa, 1991, vol. 1, pp. 329-330.

${ }^{95}$ Idem, p. 335. Veja-se também: GUEDES, Fernando - O Livro e a Leitura em Portugal. Subsidios para a sua história - séculos XVIII e XIX, Lisboa: s./n., 1987. 
Quadro n ${ }^{\circ} 3$ - Requisições feitas na Biblioteca Pública de Ponta Delgada entre 1926 e $1930^{96}$

\begin{tabular}{|c|c|c|c|c|c|}
\hline & 1926 & 1927 & 1928 & 1929 & 1930 \\
\hline Janeiro & 140 & 118 & 101 & 135 & 108 \\
\hline Fevereiro & 102 & 147 & 165 & 126 & 64 \\
\hline Março & 147 & 137 & 264 & 150 & 92 \\
\hline Abril & 127 & 145 & 3 & 116 & 100 \\
\hline Maio & 86 & 68 & 136 & 137 & 63 \\
\hline Junho & 86 & 71 & 177 & 138 & 75 \\
\hline Julho & 93 & 163 & 95 & 162 & 111 \\
\hline Agosto & 140 & 197 & 132 & 75 & 67 \\
\hline Setembro & 101 & 28 & 93 & 95 & 147 \\
\hline Outubro & 111 & 2 & 221 & 112 & 74 \\
\hline Novembro & 102 & 166 & 170 & 79 & 60 \\
\hline Dezembro & 110 & 112 & 145 & 135 & 94 \\
\hline Totais & 1345 & 1354 & 1702 & 1460 & 1055 \\
\hline
\end{tabular}

Da análise do quadro anterior ressalta o aumento das requisições comparativamente ao quadro e ao período anteriores. De um mínimo de 1055 em 1930, a um máximo de 1702 em 1928, é um facto que, neste quinquénio, os pedidos nunca foram inferiores a 1000. No entanto, é preciso ter em conta que o número de requisições não era igual ao número de leitores, dado que um só leitor podia fazer mais do que uma requisição. Se a maioria solicitava uma só obra - fosse livro ou jornal - casos havia em que os pedidos oscilavam entre dois até seis ou sete. Tratando-se de dicionários, por exemplo, o pedido podia ascender a nove requisições. Isto reduz, pois, o número de leitores em relação aos pedidos numa percentagem aproximada na ordem dos 15 a $20 \%{ }^{97}$.

Por outro lado, também já não se regista uma frequência tão diminuta nos meses de Agosto e Setembro o que atestará alterações operadas no funcionamento da instituição.

No tocante ao público leitor, também se notam diferenças. Apesar de diminutos, deparamo-nos já com leitores do sexo feminino. As excepções

\footnotetext{
${ }^{96}$ BPARPD - FBPARPD, Dep. 21, nº 7, Livro no 11, Frequências.

${ }^{97}$ Uma ressalva deve ser feita em relação aos meses de Setembro e Outubro de 1927. Algum problema terá afectado o $\mathrm{n}^{\mathrm{o}}$ de registos, pois o livro apresenta mais de metade de uma página em branco, passando logo para o final do mês seguinte.
} 
encontradas, no intervalo compreendido entre 1926 e 1930, foram as de Clotilde de Jesus que, em Setembro de 1929, requisitou Obras de Francisco Sá de Miranda ${ }^{98}$ e as de Helena Drumond e Maria Dolores da Silveira que requisitaram enciclopédias e dicionários, nomeadamente o Dicionário Universal de Educação e Ensino, bem como a obra Teoria da Educação. Estas referências testemunham, certamente, um percurso de discentes do Magistério Primário ou de docentes ${ }^{99}$. De resto, a Biblioteca Pública continuava a ser um espaço predominantemente masculino e ainda mais restritivo se pensarmos que este universo se resumia ao estrito mundo da cultura e da literacia.

Ademais, era a literatura oitocentista que continuava a predominar. Entre os livros mais requisitados deparamos com os grandes romances de autores portugueses da $2^{\mathrm{a}}$ metade da centúria. Em lugar cimeiro estava Eça de Queiroz através de obras como Os Maias, O Crime do Padre Amaro (muito solicitado), A Cidade e as Serras, O Primo Basilio, O Mandarim, A Ilustre Casa de Ramires, A Relíquia. De Júlio Dinis requisitava-se Uma Família Inglesa, Os Fidalgos da Casa Mourisca, Serões da Província, As Pupilas do Senhor Reitor e A Morgadinha dos Canaviais. Camilo Castelo Branco continuava entre os eleitos, agora com Amor de Perdição, Eusébio Macário, A Brasileira de Prazins, Mistérios de Lisboa, Romance de um Homem Rico e a colectânea de contos intitulada Doze Casamentos Felizes. O Monge de Cister, de Herculano, continuava entre as leituras da época, a par de A Ceia dos Cardeais, de Júlio Dantas e de Lisboa em Camisa, romance de Gervásio Lobato, publicado em 1890.

Da literatura portuguesa continuava-se a ler poesia, em especial, de Bocage, Sá de Miranda ou Antero de Quental. No entanto, a maior novidade é a crescente quantidade e diversidade de literatura estrangeira presente no rol de requisições. Esta particularidade vem corroborar o que sucedia, no continente, já na $2^{\mathrm{a}}$ metade do século XIX. A tendência era para um alargamento temático e do público leitor interessado na literatura de além fronteiras de onde vinham grandes nomes como os Alexandre Dumas, Vitor Hugo, Júlio Verne, Darwin, entre outros. A nível interno sobressaiam

\footnotetext{
${ }^{98}$ BPARPD - FBPARPD, Dep. 21, no 7, Livro no 11, Frequências, fl. 179.

${ }^{99}$ BPARPD - FBPARPD, Série 001, Liv. 12, nº 11, 1930-, s/ fls.
} 
Garrett, Castilho, Herculano, Camilo, Eça de Queirós que serve de ponte entre a divulgação literária e o publicismo de conhecimentos úteis ${ }^{100}$. De resto, desde esse período que "o fenómeno leitura foi-se tornando um hábito cada vez mais regular, caro aos meios da pequena e média burguesia. Surgem, então, as bibliotecas populares e as de família, com colecções de títulos variados"

Na Biblioteca Pública de Ponta Delgada eram requisitadas inúmeras obras de Júlio Verne, atestando um público maioritariamente juvenil. Eram elas: Da Terra à Lua, A Volta ao Mundo em Oitenta Dias, As Aventuras do Capitão Hatteras, Vinte Mil Léguas Submarinas, Cinco Semanas num Balão, Os Filhos do Capitão Grant, Viagem ao Centro da Terra, A Ilha Misteriosa, Miguel Strogoff, Um Herói de Quinze Anos, As Viagens Extraordinárias de Mathias Sandorf e O Doutor Ox.

Entre os livros mais solicitados contava-se o empolgante romance de Alexandre Dumas pai, O Conde de Monte Cristo. Sucediam-no As Minas de Salomão, um original de Henry Haggard que Eça traduziu, A Fada d'Auteuil, de Ponson du Terrall, O Grande Industrial, de Jorge Ohnet, Germinal, de Émile Zola, Lês Fleurs du Mal, de Baudelaire, Os Mistérios de Paris, famoso folhetim de Eugène Sue, Os Amores de Margarida de Borgonha, de Henri Demesse (de 1901), entre outros. Acresciam, por fim, os grandes clássicos como A Divina Comédia, de Dante, D. Quixote de La Mancha, de Cervantes ou $O$ Avarento, de Molière

A requisição de $A$ Rainha do Gelo, de Hans Christian Andersen e de A Gata Borralheira, em 1930, leva-nos a inferir a frequência de um público ainda mais jovem ${ }^{102}$.

Além das obras literárias, abundava a consulta de jornais micaelenses, quer da actualidade ou mais antigos (Diário dos Açores, A Persuasão, O Agricultor Micaelense, O Autonómico, O Preto no Branco, Correio dos Açores, Diário de Anúncios, A Ventosa Sarjada, O Correio Micaelense), bem como de folhas estrangeira como Le Monde Illustré. A maior circulação de livros e de publicações periódicas, ao lado do enorme incremento

\footnotetext{
${ }^{100}$ NUNES, Maria de Fátima Nunes - "O fenómeno da difusão da leitura", in REIS, António, dir. - Portugal Contemporâneo, 1851-1910, Lisboa: Alfa, 1991, vol. 2, p. 264.

${ }^{101}$ Idem, ibidem.

${ }^{102}$ FBPARPD - Série 001, Liv. 12, no 11, 1930-, s/ fls.
} 
que a imprensa conheceu (desde meados do séc. XIX) foi permitindo, gradualmente, articular, sobre novos alicerces, o pensamento nacional e insular, também mais enriquecido com as leituras estrangeiras.

De resto, avultava também a consulta de enciclopédias (como a Enciclopédia Portuguesa Ilustrada) e de dicionários ${ }^{103}$, bem como de crónicas e obras de temática histórica nacional, insular e estrangeira, tais como: Portugaliae Monumenta Histórica, História Insulana, História de Portugal, História das Índias, Saudades da Terra, Anais da Ilha Terceira, L'Histoire de France, O Ultimatum de 31 de Janeiro, Manuel d'Histoire Universelle, História da Revolução Francesa ou História da Revolução do Porto de 1820. Acresciam algumas biografias ${ }^{104} \mathrm{e}$ fontes documentais como a Nobiliarchia Conimbricense, o Arquivo dos Açores, extratos de registos paroquiais micaelenses e de árvores genealógicas (naturalmente do acervo de Ernesto do Canto). Mais esporádicas eram as consultas dos Sermões do Padre António Vieira, da Revista Militar, de Elementos de Electricidade ou do Código Civil Português. Ou ainda de obras como Critique de la Raison Pure, Histoire da la Littérature Grecque, Álgebra Elementar, Traité de Medicine ou La Philosophie de Shopenhauer - estes últimos certamente requisitados por estudantes do Liceu.

Como acabamos de verificar, a literatura estrangeira começava a ombrear com a literatura portuguesa, enquanto os clássicos se mantinham ao lado dos modernos. A par de obras de referência e de consulta, registavam-se as grandes obras da História e os compêndios próprios de meio escolar. Avolumava-se, também, a consulta de fontes manuscritas, própria de alguns curiosos e eruditos, bem como a leitura corrente dos jornais. No entanto, apesar das rupturas impostas pela revolução de 5 de Outubro de 1910, os valores culturais e ideológicos mantiveram-se muito atreitos às persistências do século XIX. Inclusive, no tocante ao público leitor.

${ }^{103}$ Por exemplo: Dicionário Clássico de Língua Portuguesa, Dicionário de Morais, Dicionário de Inocêncio, Elucidário de Viterbo, Dicionário Cândido de Figueiredo, Novo Dicionário Português e Italiano, Dictionaire Classique, Dicionário Latino-Português ou o Petit Larousse.

${ }^{104}$ De reis de Portugal, do Marquês de Pombal, de Luís de Camões, de Cristóvão Colombo, do Marquês de Niza ou de santos da Igreja. 
Tal como na $2^{\mathrm{a}}$ metade de oitocentos, os próprios nomes denunciam os respectivos estratos sociais de pertença: elites e alguma classe média alta, onde se destacavam intelectuais e homens de letras de considerável envergadura e entre os quais se podiam contabilizar, novamente, padres e militares ${ }^{105}$. Frequentadores assíduos eram, por exemplo, Cristóvão de Sousa Lima, Ernesto Machado Macedo, Antero da Silva Rocha, Aires Soares de Albergaria Tavares Silva, Rodrigo Rodrigues (genealogista), João de Simas (o próprio bibliotecário), Duarte Melo, José do Canto Pereira Serpa, Nicolau Augusto d'Arruda Quental, Albano de Vasconcelos Viveiros, Clemente Joaquim da Costa Canejo (próspero negociante), Porfírio Bessone de Medeiros (escritor), Gonçalo Velho Quintanilha Falcão, Henrique da Cunha Álvares Cabral, os Drs. Humberto Bettencourt de Medeiros e Câmara, Luís Bernardo Leite Ataíde (versátil estudioso e etnógrafo), Felix José da Costa Sotto Maior, Manuel Caetano Pereira, Manuel de Lacerda de Almeida, Urbano de Mendonça Dias (historiador), Jaime Tavares Netto, Francisco Espínola de Mendonça, Armando Cortes-Rodrigues (escritor, poeta, dramaturgo), Virgílio Pereira da Silva, Oscar Medeiros Bettencourt, José Pires de Carvalho, José Bruno Carreiro (jurista, jornalista, escritor e político), entre muitos outros. Possivelmente, entre as paredes da sala de leitura, gizaram muitos dos seus trabalhos e publicações, alguns deles imbuídos de verdadeiro espírito regionalista e autonomista.

\section{Concluindo...}

Em 1946, por ocasião da celebração do IV centenário da cidade de Ponta Delgada, Aníbal Bicudo, autor de um trabalho evocativo da efeméride, ao referir-se à Biblioteca Pública - uma das mais importantes instituições

${ }^{105}$ Capitães Eduardo dos Reis Rebelo, Tibúrcio Carreiro da Câmara, Major Manuel Silvestre de Abreu, Coronel Virgílio Soares de Albergaria, Tenente José Batista Barreiros, Capitão Joaquim Monteiro Arruda, Capitão-Tenente Alfredo Botelho de Sousa que, além de jornais, requisitou obras como East Índia Compay's records.e ainda o Capitão Bernardino de Matos Todela Vasconcelos. Padres Manuel Vicente, António do Presépio Moniz. Manuel Ernesto Ferreira. 
urbanas - dizia ser esta uma das obras mais úteis legadas pelos governos liberais. Um verdadeiro "Remédio d'Alma - no palavroso dizer de então"106.

De facto, não obstante as inúmeras dificuldades com que se deparou esta Biblioteca ao longo de sucessivas décadas, por via de constrangimentos financeiros, de escassez de recursos humanos e até de desadequadas instalações, a Biblioteca Pública micaelense desempenhou (e ainda desempenha) um relevante papel na divulgação da cultura escrita e do conhecimento - ajudando a rasgar os limitados horizontes insulares - e na conservação / preservação de colecções e variadas espécies, abarcando um importante espólio que muito deveu a doações de particulares e também às aquisições oficiais.

O percurso oitocentista desta instituição não terá sido muito distinto do das demais bibliotecas públicas nacionais que, desempenhando idêntico papel cultural e patrimonial, também se depararam com períodos de dificuldades e de marasmo, acomodando-se, por longas décadas, em laicizados edifícios conventuais e incorporando as respectivas colecções e outras de diversificada proveniência. De realçar o prolongamento dos horários de funcionamento, as melhorias nos empréstimos domiciliários e os esforços efectuados no tocante à inventariação, publicação de catálogos e organização de exposições bibliográficas. Para isto muito contribuiu a evolução a nível da divulgação de conhecimentos, configurada nos progressos das técnicas de impressão, nos processos de compilação e de edição e no notável movimento das colecções literárias ${ }^{107}$.

${ }^{106}$ BICUDO, Aníbal - Em Louvor ... cit., p. 55.

${ }^{107}$ TORGAL, Luís Reis e VARGUES, Isabel Nobre - "Espaços de...cit”, p. 690-691. 